\title{
Mitochondrial and Autophagic Regulation of Adult Neurogenesis in the Healthy and Diseased Brain
}

\author{
Hansruedi Büeler
}

check for updates

Citation: Büeler, H. Mitochondrial and Autophagic Regulation of Adult Neurogenesis in the Healthy and Diseased Brain. Int. J. Mol. Sci. 2021, 22, 3342. https://doi.org/10.3390/ ijms 22073342

Academic Editor: Estela Castilla Ortega

Received: 24 February 2021

Accepted: 19 March 2021

Published: 24 March 2021

Publisher's Note: MDPI stays neutral with regard to jurisdictional claims in published maps and institutional affiliations.

Copyright: (C) 2021 by the author. Licensee MDPI, Basel, Switzerland. This article is an open access article distributed under the terms and conditions of the Creative Commons Attribution (CC BY) license (https:/ / creativecommons.org/licenses/by/ $4.0 /)$.
School of Life Sciences and Technology, Harbin Institute of Technology, Harbin 150080, China; hbueler@hit.edu.cn

\begin{abstract}
Adult neurogenesis is a highly regulated process during which new neurons are generated from neural stem cells in two discrete regions of the adult brain: the subventricular zone of the lateral ventricle and the subgranular zone of the dentate gyrus in the hippocampus. Defects of adult hippocampal neurogenesis have been linked to cognitive decline and dysfunction during natural aging and in neurodegenerative diseases, as well as psychological stress-induced mood disorders. Understanding the mechanisms and pathways that regulate adult neurogenesis is crucial to improving preventative measures and therapies for these conditions. Accumulating evidence shows that mitochondria directly regulate various steps and phases of adult neurogenesis. This review summarizes recent findings on how mitochondrial metabolism, dynamics, and reactive oxygen species control several aspects of adult neural stem cell function and their differentiation to newborn neurons. It also discusses the importance of autophagy for adult neurogenesis, and how mitochondrial and autophagic dysfunction may contribute to cognitive defects and stress-induced mood disorders by compromising adult neurogenesis. Finally, I suggest possible ways to target mitochondrial function as a strategy for stem cell-based interventions and treatments for cognitive and mood disorders.
\end{abstract}

Keywords: adult neurogenesis; hippocampus; mitochondrial metabolism; mitochondrial dynamics; reactive oxygen species (ROS); autophagy/mitophagy; neurodegeneration; cognitive dysfunction; psychological stress; mood disorders

\section{Introduction}

Neurogenesis produces new neurons from neural stem cells (NSC) and is essential for brain development. In addition, NSC and neurogenesis occur in two discrete regions of the adult brain: the subventricular zone (SVZ) of the lateral ventricle and the subgranular zone (SGZ) of dentate gyrus (DG) in the hippocampus [1]. In these two areas, radial glia-like NSC self-renew or give rise to transiently proliferating intermediate progenitor cells (IPC) that subsequently form neuroblasts. In the SVZ, neuroblasts migrate along the rostral migratory stream to reach the olfactory bulb $(\mathrm{OB})$, where newborn neurons mature and form synapses with existing olfactory sensory neurons. Functional integration of newborn neurons adds plasticity to the OB circuitry and is important for olfactory discrimination, learning, and memory [2,3]. In the hippocampus, neuroblasts migrate into the granule cell layer, where they differentiate into mature neurons that integrate into the existing DG circuitry [4]. Adult hippocampal neurogenesis (AHN) is important for spatial and contextual pattern separation, which requires the DG [5,6] and depends on immature, adult-born granule neurons that display increased excitability and plasticity [7-9]. Blocking neurogenesis in mice by focal X-ray irradiation reduced spatial learning and memory performance, but only when the cues were presented with little spatial separation [10]. Likewise, conditional ablation of the GDNF receptor GFR $\alpha 1$, which inhibited dendritic maturation of immature DG granule cells, impaired the ability of mice to distinguish between identical objects placed in similar, but not dissimilar, locations [11]. Several other groups confirmed that deficits of AHN compromise pattern separation [12-15]. In contrast, 
promoting AHN through moderate exercise $[16,17]$ or by inducible genetic expansion of newborn neurons [18] improved performance in spatial pattern separation tasks.

There is some controversy as to whether adult neurogenesis is maintained throughout life in humans or ends between childhood and early adult life. Several groups detected proliferating NSC as well as immature and mature newborn neurons in the DG even in aged humans [19-21]. However, other groups have argued that hippocampal neurogenesis declines sharply in children and becomes undetectable in adults [22]. Time translation studies that allow for cross-species comparisons showed that hippocampal neurogenesis is a continuous process that starts during embryonic brain development [23] and plateaus out at a low level in all species as they age, and it has been suggested that even low levels of neurogenesis in adult humans could be sufficient to affect certain behaviors and mitigate age-dependent cognitive defects $[24,25]$. The discrepancy between two recent, seemingly similar studies $[20,22]$ may be explained by differences in sampling postmortem brain tissue, different methods for cell quantification, and interpretation of cell types, or a combination thereof. Collectively, the studies highlight the need for standardized procedures and better markers for neurogenesis when working with postmortem tissue [26-29].

\section{Metabolic Regulation of Stem Cell Maintenance versus Differentiation}

We have a considerable understanding of the extracellular cues (e.g., morphogens, neurotrophic and growth factors, cytokines) and intracellular signaling pathways (e.g., Notch and Wnt signaling, transcription factors, miRNAs, cell cycle regulators) that control adult NSC maintenance, activation, proliferation, and neuronal differentiation [30,31]. In contrast, the regulatory function of mitochondria and cell metabolism during adult neurogenesis has only recently been illuminated.

Mitochondrial function and dynamics are crucial for the control of cell proliferation and differentiation [32-34]. Stem cells either self-renew to maintain stemness or differentiate into tissue-specific cells, and the balance between self-renewal and differentiation is regulated by dynamic changes in cell metabolism. In the hematopoietic system and the heart, stemness is associated with glycolysis [35-38]. In contrast, differentiation of stem cells into mature cells requires a switch from glycolysis to increased mitochondrial respiration to satisfy the increased energy demand of differentiated cells $[35,36,38-40]$. Likewise, differentiation of induced pluripotent stem cells (iPSC) involves remodeling of the mitochondrial network for increased mitochondrial activity, while reprogramming of somatic cells to iPSC demands an opposite transition from mitochondrial oxidative phosphorylation (OXPHOS) to glycolysis [41-43].

In iPSC-derived NPC, the switch from glycolysis to OXPHOS is characterized by downregulation of glycolytic enzymes hexokinase (HK2) and lactate dehydrogenase (LDHA) and increased expression of pyruvate kinase 1 [44]. Constitutive overexpression of HK2 and LDHA during NPC differentiation caused neuronal death, showing that shutting off glycolysis to promote OXPHOS is a prerequisite for neuronal differentiation of iPSC [44]. Early indications that cell metabolism is also crucial for adult neurogenesis came from the observation that a diet enriched in poly-unsaturated fatty acids induced neurogenesis in the SVZ and the DG of adult mice [45]. Later, mice with a conditional ablation of fatty acid synthase in NSPC provided direct confirmation that lipid metabolism regulated adult neurogenesis [46], and this has since been corroborated by several other studies [47-49]. NSPC sustained aerobic respiration by expressing enzymes required for fatty acid oxidation (FAO), which increased their proliferation [50]. In addition, FAO by carnitine palmitoyltransferase 1a (Cpt1a) was high in qNSC but reduced in proliferating NSPC, suggesting that a high rate of FAO is required for NSC maintenance [51]. An in-depth review on how lipids regulate NSC function has recently been published [52].

Collectively, these studies showed that stem cells rely primarily on glycolysis and FAO, and that a progressive transition to OXPHOS is required for the differentiation of stem cells of many, if not all, tissues. Figure 1 depicts a simplified scheme of the cell metabolic pathways discussed in this review. 


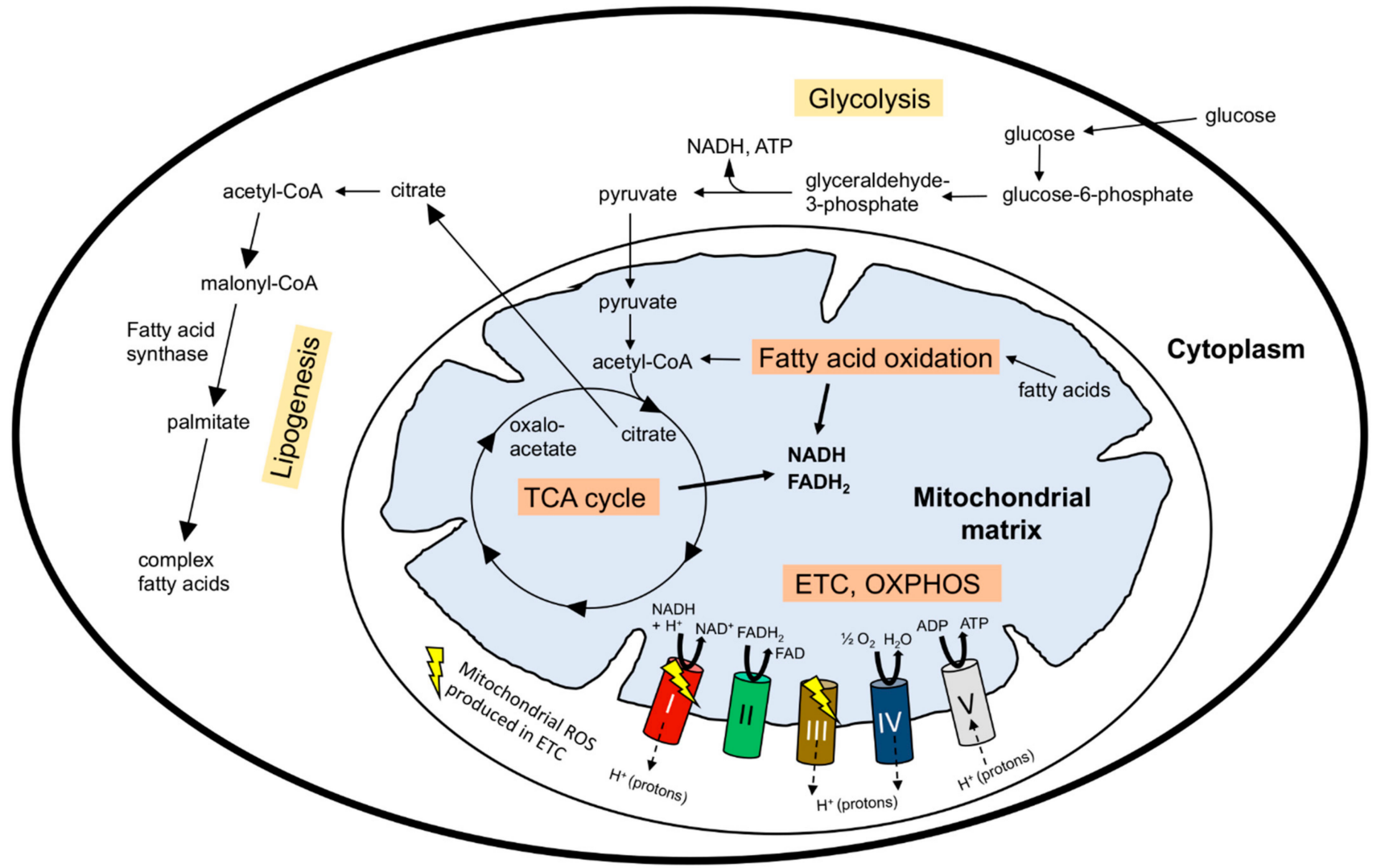

Figure 1. Simplified depiction of the cellular metabolic pathways discussed in this review. Glycolysis converts glucose into pyruvate that is transported into mitochondria and converted to acetyl-CoA. Acetyl-CoA is also produced during fatty acid oxidation (FAO) in the mitochondrial matrix. Acetyl-CoA enters the tricarboxylic acid (TCA) cycle that produces the substrates $\mathrm{NADH}$ and $\mathrm{FADH}_{2}$ (for respiratory complex I and II, respectively) required for oxidative phosphorylation (OXPHOS). Electron transport during respiration is coupled to proton $\left(\mathrm{H}^{+}\right)$export from the mitochondrial matrix to the inter-membrane space. This generates an electrochemical gradient $\Delta \psi \mathrm{m}$ where the $\mathrm{H}^{+}$concentration is higher in the inter-membrane space than in the matrix. When $\mathrm{H}^{+}$flow back into the matrix through ATP synthase (complex V), the energy of this gradient is used to produce ATP. During OXPHOS, electrons leak at respiratory complex I and III and react with molecular oxygen to produce ROS (superoxide, which is converted to $\mathrm{H}_{2} \mathrm{O}_{2}$ ). In addition to the TCA cycle, NADH and $\mathrm{FADH}_{2}$ are produced during FAO. Citrate produced in the TCA cycle exits mitochondria and is converted back to acetyl-CoA in the cytoplasm, where it is used to generate complex fatty acids through de novo lipogenesis. For FAO, complex fatty acids must be transported into the mitochondrial matrix via a carnitine shuttle system and two distinct transporters located in the outer and inner mitochondrial membrane. For simplicity, transporter proteins for various molecules are not shown in the figure. Arrows with dashes indicate the direction of proton $\left(\mathrm{H}^{+}\right)$transport/flow between the mitochondrial matrix and the intermembrane space.

\section{Mitochondria Regulate Adult Neural Stem Cell Function and Neurogenesis}

Mitochondria not only produce ATP, but also act as cellular signaling hubs through the release of metabolites, reactive oxygen species (ROS), and proteins. As such, mitochondria directly influence cytosolic signaling pathways and regulate nuclear gene transcription via mitochondria-to-nucleus retrograde communication and epigenetic gene modifications [53]. In addition, mitochondria undergo dynamic morphological changes through fission and fusion events, which are referred to as mitochondrial dynamics [34]. Recent work has shown that mitochondrial metabolism, ROS signaling, and dynamics all have crucial functions for NSPC and throughout adult neurogenesis. Although I discuss these topics in separate paragraphs below, they are closely and functionally connected. For example, mitochondrial fission is linked to ROS production and a prerequisite for mitophagy that degrades depolarized and aged mitochondria, whereas fusion is required to maintain a 
functional mitochondrial population in cells by enabling the exchange of contents between mitochondria, thereby allowing damaged mitochondria to regain lost essential components such as mitochondrial DNA $[34,54,55]$.

\subsection{Mitochondrial Metabolism-Regulated Adult Neurogenesis}

Single-cell RNA sequencing revealed that quiescent NSC (qNSC) in the adult hippocampus rely on glycolysis and fatty acid oxidation (FAO) and have low protein synthesis, while OXPHOS and protein synthesis are upregulated during the transition of qNSC to become activated NSC (aNSC) and later IPC [56]. Several groups have studied how knockout of genes encoding mitochondrial proteins affects adult neurogenesis. Conditional deletion in mice of succinate dehydrogenase subunit $\mathrm{D}(S d h d)$ in cells of the astrocyte lineage, which includes NSPC of the adult SVZ and DG, impaired differentiation of NPC to neurons and oligodendrocytes without affecting the generation, maintenance, and multi-potency of adult NSC [57]. We found similar phenotypes in mice lacking PTEN-induced kinase 1 (PINK1), mutations in which cause recessive familial Parkinson's disease [58]. Cultured hippocampal NSPC from PINK1-deficient mice displayed reduced mitochondrial membrane potential $(\Delta \psi \mathrm{m})$ and respiration, increased glycolysis, increased apoptosis, and decreased capacity for neuronal differentiation, as shown by fewer $\mathrm{DCX}^{+}$immature neurons and defects in dendritic maturation [58]. In the DG, PINK1 loss delayed the differentiation and reduced dendritic complexity of immature $\mathrm{DCX}^{+}$neurons [58]. Severe mitochondrial dysfunction in NSPC also affected proliferation and cell fate decisions of NSPC, in addition to compromising differentiation of newborn neurons. For example, conditional ablation of mitochondrial transcription factor A (Tfam) in NSC of the DG led to a selective reduction of IPC counts and overall reduced proliferation of hippocampal NSPC [59]. Glycolysis- and FAO-related genes were expressed in qNSC and aNSC of the hippocampus but became downregulated in IPC at the same time as expression of mitochondrial genes increased, suggesting that mitochondrial function is already important to promote the transition from aNSC to IPC [59]. In addition, conditional astrocyte lineage-specific deletion of the mitochondrial complex I subunit Ndufs2 during mouse development reduced the proliferation of NSPC isolated from the SVZ and resulted in abnormal cortex development and early postnatal death [60]. Although the average number of proliferating $\left(\mathrm{EdU}^{+}\right) \mathrm{NSPC}$ in the DG was also lower in PINK1-deficient mice (in several experiments), this effect did not reach statistical significance [58]. It is likely that conditional Tfam knockout causes more severe mitochondrial defects than PINK1 deficiency, because Mito-Park mice with a Tfam deletion [61], but not PINK1-deficient mice [62], showed degenerative changes of the dopaminergic system. Based on these studies, it might be proposed that mild mitochondrial dysfunction primarily compromises differentiation of adult-born neurons in the DG due to absolute dependence of differentiated neurons on OXPHOS, while severe defects of mitochondrial bioenergetics (as in Tfam and Ndufs2 knockouts, which may lead to oxidative stress) also impair NSPC proliferation and survival due to the increased dependence of IPC on mitochondrial metabolism. Alternatively, inhibitory effects of mitochondrial deficits on NSPC proliferation may have been partially reversed by compensatory increased glycolysis in NSPC of PINK1-deficient mice, as glycolysis promotes and is sufficient to maintain proliferation of stem cells [39].

\subsection{Regulation of Adult Neurogenesis by Mitochondrial Dynamics}

Mitochondrial dynamics refers to alterations of mitochondrial morphology and subcellular distribution, which is controlled by proteins that promote fission or fragmentation (Drp1, Fis1), fusion (Mfn1/2, Opa1), and transport (Miro, Milton) of mitochondria [34]. Mitochondrial dynamics is required for normal development and cell function, including differentiation and the cell cycle [32,34]. Mutations in mitochondrial fusion genes cause hereditary neuropathies Charcot-Marie-Tooth disease 2A and autosomal-dominant optic atrophy [34], and abnormalities of mitochondrial dynamics are implicated in the pathogenesis of several neurodegenerative disorders, most notably Parkinson's disease [63]. 
Studies with Drp1-knockout mice revealed that aberrant mitochondrial dynamics compromises neuronal differentiation and synapse formation during development [64,65]. That mitochondrial dynamics also regulates AHN was demonstrated later by infection of hippocampal NSC with a retrovirus expressing mitochondria-targeted GFP, which allowed permanent labeling of mitochondria in the neurogenic lineage [66]. This revealed that, during differentiation of newborn DG granule neurons, the mitochondrial mass increases dramatically (indicative of mitochondrial biogenesis), coupled with increased mitochondrial fission and distribution of mitochondria from the soma to dendrites of newborn neurons [66]. Voluntary running, which promotes AHN, enhanced these mitochondrial network alterations [66]. Importantly, only a few newborn neurons survived one week after infection of NSC with a retrovirus that co-expressed dominant-negative Drp1 (dnDrp1, which inhibits fission) and mitochondrial GFP, and these neurons had very few mitochondria and failed to extend dendrites into the granule cell layer [66]. Taken together, these results show that mitochondrial biogenesis and fission are essential for the differentiation of neurons by supplying sufficient mitochondria into growing dendrites of adult-born neurons [66]. In another study, failure to distribute mitochondria into dendrites of mice that lack the mitochondrial transport protein Miro1 caused neurodegeneration, corroborating that active transport of mitochondria into dendrites is crucial to sustain dendritic arborization and promote dendritic complexity [67].

PINK1 promotes the degradation of depolarized mitochondria through mitophagy in cooperation with Parkin [68]. We and others have shown that lack of PINK1 alters mitochondrial dynamics, resulting in elongated and swollen mitochondria with cristae degeneration in primary cortical neurons of PINK1-deficient mice [69], Drosophila lacking PINK1 [70], and primary hippocampal neurons with RNAi-induced PINK1 knockdown [71]. Shifting the balance of mitochondrial dynamics toward increased fusion in PINK1-deficient neurons [69] may have opposed the mitochondrial fission-dependent dendritic maturation of adult-born DG neurons [66], thereby causing defects in the differentiation of $\mathrm{DCX}^{+}$neurons in mice lacking PINK1 [58].

Khacho et al. showed that inducible knockout of the mitochondrial fusion proteins Mfn1/2 in adult hippocampal NSC reduced the numbers of uncommitted Sox $2^{+}$NSC and immature $\mathrm{DCX}^{+}$neurons in the DG [72]. Acute knockdown of mitochondrial dynamics proteins Mfn2, OPA-1, and Drp1 in Sox $2^{+}$NSC showed that aberrant mitochondrial dynamics impacted on NSC self-renewal and fate decisions through changes in ROS signaling, while ATP levels were unaffected [72]. A substantial fraction of adult NSC is derived from a subpopulation of proliferating embryonic NPC $[73,74]$. To study effects of respiratory chain defects on embryonic neurogenesis and the consequences of mitochondrial dysfunction in embryonic NSPC on AHN later in life, the mitochondrial oxidoreductase AIF was conditionally deleted in vivo in uncommitted NSPC in the early (E9) telencephalon [75]. This led to excessive mitochondrial fission and ROS production at E15.5 associated with impaired self-renewal of Sox ${ }^{+}$NSC, enhanced proliferation and impaired cell cycle exit of $\mathrm{Tbr}^{+} \mathrm{NPC}$, and abnormal development of the hippocampus [75]. As a result, adult mice showed depletion of Sox $2^{+}$NSC in the DG and a complete lack of AHN as manifested by the absence of $\mathrm{DCX}^{+}$immature neurons [75].

Mitochondrial dynamics also regulates neurogenesis in the adult SVZ, which was shown in neurosphere cultures with SVZ-derived adult NSC [76]. In these cultures, mitochondria were localized at the leading process of migratory NSC, and inhibiting Drp1 with Mdivi-1 reduced migration of NSC out of neurospheres and their differentiation to neurons [76].

Collectively, these studies show that mitochondrial fission not only supports differentiation of newborn hippocampal neurons [66], but also regulates early hippocampal NSC fate decisions such as self-renewal and commitment to neuronal differentiation through ROS signaling [72]. On the other hand, excessive fission and ROS production contribute to neurodegeneration and are detrimental for neurogenesis $[75,77,78]$. Thus, a tightly regulated physiological balance between fission and fusion is crucial for normal neurogenesis. 


\subsection{Regulation of Adult Neurogenesis via Reactive Oxygen Species (ROS) Signaling}

Likewise, cellular ROS levels must be tightly controlled. Physiological ROS fulfill important signaling functions in cells and tissues, including during neurogenesis [79-82]. However, overproduction or impaired detoxification of ROS causes oxidative stress, which contributes to aging, several disorders including neurodegeneration, and impairs neurogenesis [83-85]. ROS are produced by mitochondria, NADPH oxidases, and peroxisomes, with the major source being mitochondrial respiration.

Neurogenesis itself transiently produces ROS, as shown in experiments with cultured adult hippocampal NSC, where neuronal differentiation is accompanied by an increase of mitochondrial content and ROS levels [86]. Moreover, markers of oxidized DNA and lipids accumulated in the SGZ of the DG, which was reduced by pharmacological inhibition of neurogenesis [86]. As discussed above, acute experimental disturbances of mitochondrial dynamics in Sox $2^{+}$NSC affected the decision between NSC self-renewal and differentiation through changes in ROS signaling [72]. Specifically, the transition from a NSC to a committed IPC required mitochondrial fragmentation, which triggered a ROS- and Nrf2dependent transcriptional program, overall increasing expression of differentiation genes and suppressing self-renewal genes [72]. A more recent study-which FACS-sorted NSPC according to ROS levels and carried out marker and transcriptome analyses on subgroups of NSPC with decreasing ROS levels-unexpectedly showed that the cells with the highest ROS levels were qNSC [87]. Shifts to lower ROS content primed NPC for a subsequent state transition, whereby lower ROS levels correlated with increased expression of proliferation and differentiation genes [87]. In addition, a transient Nox2-dependent burst of ROS production (over the already high levels of basal ROS) promoted exercise-induced recruitment of qNSC for proliferation, but Nox2 was not required for NSPC proliferation under physiological conditions [87]. While these results seemingly contradict earlier results [72], they may not be mutually exclusive, because the transient nature of ROS and ROS signals likely triggers cell transitions without substantially altering ROS levels in the next cell type, especially if the ROS burst also activates anti-oxidative genes [72]. Measuring ROS levels in vivo and at a higher temporal resolution may be necessary to resolve these discrepancies.

In addition to mitochondria, NADPH oxidases (Nox) are the second major source for intracellular ROS [79]. Several Nox enzymes regulate self-renewal, proliferation, and differentiation of NSC during embryonic and adult hippocampal neurogenesis through $\mathrm{PI} 3 \mathrm{~K} / \mathrm{Akt}$ and MAPK/Erk signaling pathways, which has been described in an excellent recent review [79].

Because ROS are central in the regulation of neurogenesis, it is not surprising that environmental or genetic factors, injury, or chronic disease that alter ROS levels can also affect neurogenesis. For example, Nox2 deletion in mice decreased the population of radial glia-like NSC and neuroblasts under physiological conditions [88]. Despite this, within one week after traumatic brain injury (TBI), Nox2-knockout mice showed increased numbers of neuroblasts, and five weeks after TBI they had significantly more surviving newborn neurons compared to wild type mice [88]. These results suggest that Nox2-derived ROS are necessary to maintain radial glia-like NSC under physiological conditions, but impair the proliferation of NSPC and neuroblasts under pathological conditions such as TBI due to over-activation of Nox2. Likewise, SVZ-derived NPC from mice deficient for the clock gene Bmal1 showed oxidative stress due to aberrant expression and inactivation of anti-oxidant genes, which compromised NPC proliferation and migration along the rostral migratory stream [89]. Ischemia - which is associated with a surge of oxidative stress-increased the number of newborn neurons in the DG in an Nrf2-dependent manner, and Nrf2 overexpression in cultured hippocampal NSPC enhanced neuronal differentiation, while Nrf2 deficiency exacerbated the detrimental effects of amyloid- $\beta$ (A $\beta$ ) on AHN in mice [90]. Taken together, these studies show that physiological ROS produced by mitochondria and NADPH oxidases critically regulate NSC self-renewal, proliferation, and differentiation in a stage-specific manner, but that excessive and prolonged ROS production (e.g., induced by TBI or $A \beta$ ) is detrimental for the survival and maturation of newborn neurons. While 
the pleiotropic extrinsic factors and intracellular signaling pathways that regulate adult neurogenesis have been described elsewhere [30,31], several key transcription factors and signaling pathways mediate the effects of ROS on adult and embryonic neurogenesis, including Notch and Wnt/ $\beta$-catenin [72,91], Nrf2 [72,90], p53 [92], PI3K/Akt [92-94], and pErk1/2 [95].

\section{Regulation of Adult Neurogenesis by Autophagy and Lysosomal Degradation}

Autophagy is a conserved lysosomal degradation pathway that influences cell survival and metabolism by clearing cells from harmful protein aggregates and damaged organelles, including depolarized mitochondria through mitophagy $[55,96]$. Autophagy is regulated by nutrient availability and cellular energy status-as well as induced by oxidative stress-and mediated by diverse signaling pathways, including PI3K/Akt, AMPK, and inhibition of mTORC1 [96]. Figure 2 depicts a simplified diagram of autophagy and mitophagy.
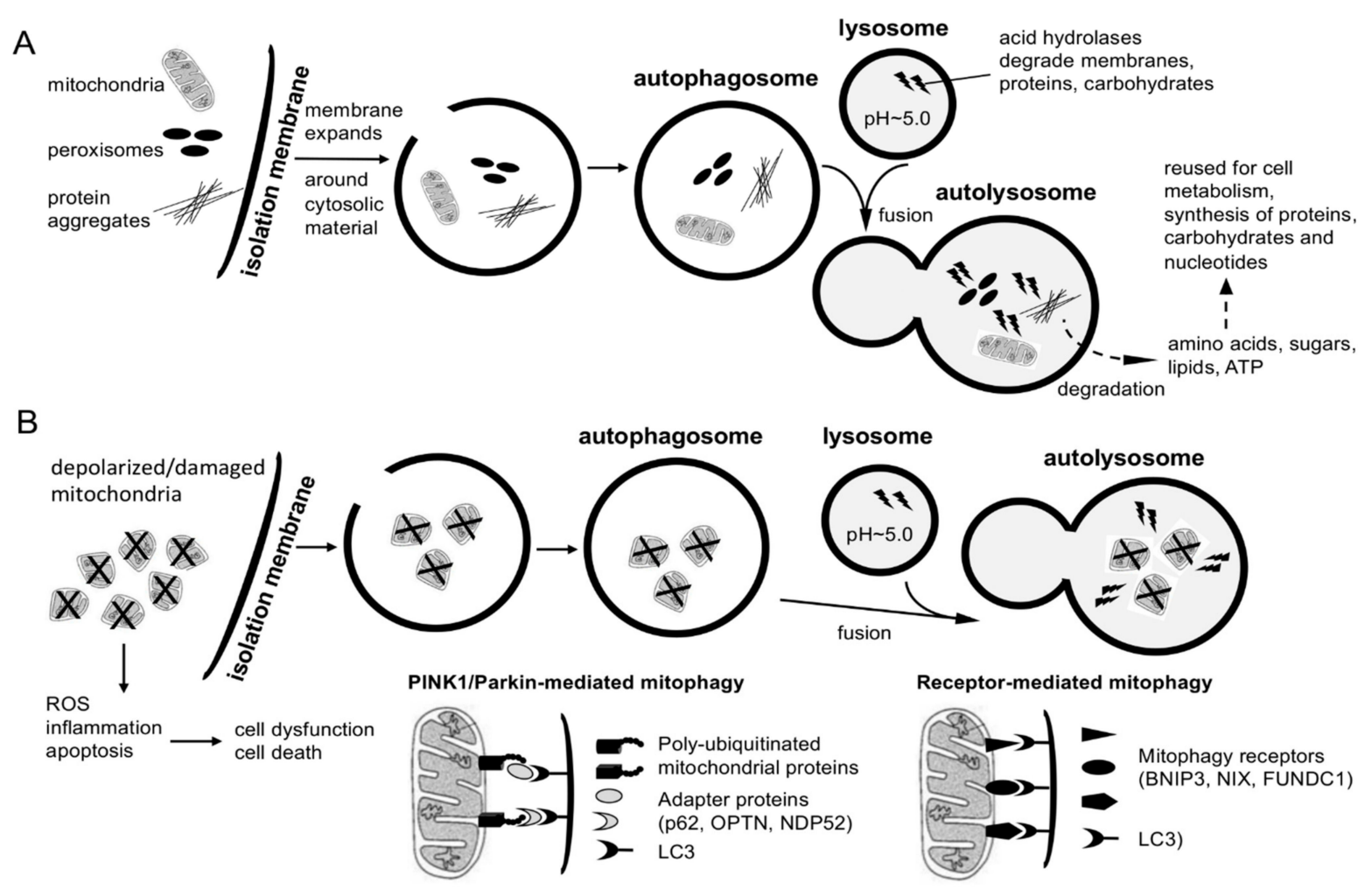

Figure 2. Simplified scheme of autophagy and mitophagy pathways. (A) Basal macro-autophagy (autophagy) degrades and recycles cellular contents at steady state. The activity of autophagy is regulated by nutrient (e.g., glucose) and energy (AMP/ATP ratio) availability through PI3K/Akt signaling, mTORC1, and AMPK. Autophagy is induced under conditions of nutrient and energy starvation and by oxidative stress, i.e., conditions that require enhanced recycling of cellular materials to sustain cell metabolism and degradation of oxidized and aggregated proteins to protect cells against stress-induced damage. At the start of autophagy, a double membrane (isolation membrane or phagophore) forms and expands around the cellular material to engulf the material within an autophagosome. The autophagosome fuses with a lysosome that contains hydrolases necessary to degrade the contents within the resulting autolysosome. For details, including stage-specific autophagy regulators, please refer to [96]. (B) Mitophagy is a subclass of autophagy that selectively degrades depolarized and damaged mitochondria. There are two mitophagy mechanisms (for details, see [55,68]). In PINK1/Parkin-dependent mitophagy, PINK1 selectively accumulates on depolarized mitochondria (due to import deficiency), and PINK1 and Parkin cooperate to poly-ubiquitinate specific proteins at the surface of depolarized mitochondria. PINK1-phosphorylated polyubiquitin serves a signal for autophagy adapters (p62, OPTN, NDP52) to bind to the damaged mitochondria and target them to autophagosomes via interaction with LC3 of the isolation membrane. In receptor-mediated mitophagy, mitophagy receptors (BNIP3, NIX, FUNDC1) localize to the mitochondrial membrane and directly interact with LC3. 
The key autophagy genes Ambra-1 and Beclin-1 are expressed in the SVZ [97], and autophagic flux was demonstrated in adult hippocampal NSC and their progeny by infecting hippocampal NSC with a retrovirus encoding mCherry-EGFP-LC3 [98]. Targeting genes and miRNAs that regulate autophagy induction and promote autophagic flux, including Beclin-1, Atg5, let-7, and the Forkhead Box O (FoxO) family of transcription factors led to defects of adult NSPC renewal, proliferation, migration, and differentiation in the SVZ $[97,99,100]$ and the DG $[98,101,102]$. Some of these defects could be rescued by pharmacological induction of autophagy with rapamycin [101] or over-expression of the autophagy inducer Beclin-1 and the transcription factor EB (TFEB), a master regulator of autophagy and lysosomes [99].

FoxO family transcription factors have an essential role in preserving the NSC pool by maintaining a physiological balance between NSC self-renewal and differentiation. Tripleknockout mice deficient for FoxO1, FoxO3, and FoxO4 showed initial hyper-proliferation of NSPC in early adult life, followed by depletion of NSC and severely impaired neurogenesis in the SVZ of adult mice [100]. FoxO3 activity was higher in self-renewing adult NSC than in differentiated progeny, and FoxO3 prevented premature NSC depletion and differentiation by inducing a transcriptional program to preserve NSC quiescence [102]. Using cultured NSC isolated from the SVZ of adult mice, it was shown that FoxO3 directly regulates an autophagy network, binding to and activating about one third of the known autophagy genes as well as several key mitophagy genes, including Pink1, Bnip3, and Bnip3L, thereby increasing autophagic flux [103].

In addition, emerging evidence suggests that mitophagy may regulate both stemness and differentiation of stem cells, possibly in a tissue-specific manner [104]. Indeed, given that mitochondria have essential roles throughout neurogenesis, it is likely that mitophagy — a subclass of autophagy that selectively degrades damaged mitochondria-is also important in this process.

Finally, autophagy is part of a lysosomal degradation pathway, and recent transcriptome profiling has shown that lysosomal function regulates SVZ neurogenesis [105]. Specifically, qNSC in young mice digest accumulating protein aggregates slowly within lysosomes, whereas aNSC rely mostly on proteasomal protein degradation. Activation of qNSC by growth factors increased lysosomal protein degradation, while inhibiting lysosomal activity with bafilomycin-A reduced growth factor-induced protein degradation and activation of qNSC. Age-dependent lysosomal dysfunction also impaired activation of qNSC, which could be corrected by expression of TFEB [105].

Taken together, these studies show that physiological autophagy and lysosomal degradation are crucial for NSC maintenance as well as NPC proliferation, survival, and differentiation to newborn neurons in both the SVZ/OB and the DG.

\section{Psychological Stress-Induced AHN Defects and Mood Disorders: Contribution of Mitochondrial and Autophagic Dysfunction}

In addition to its role in cognitive flexibility [7-10], AHN provides a buffer against stress-induced depression and anxiety by blunting the brain hypothalamic-pituitaryadrenal (HPA) stress response and/or accelerating recovery from pathologically augmented HPA axis activity [106-110]. Unpredictable averse experiences, or stressors, activate the HPA stress-signaling axis that culminates in the secretion of cortisol in humans and corticosterone in rodents. These glucocorticoids cause physiological and behavioral responses that serve to protect the organism against acute stressors. Importantly, signaling through glucocorticoid receptors expressed in neurons of the hippocampus provides negative feedback inhibition onto the HPA stress response [111,112], resulting in a transient stress response. However, chronic over-activation of the HPA axis-which occurs when a stressor or threat persists-impedes the negative feedback inhibition of the hippocampus and is strongly linked to development of major depression and anxiety disorders [112].

Chronic stress decreases the proliferation of NSC and the survival of newborn neurons in the adult DG $[113,114]$. Moreover, stress-induced deficits of AHN have been linked with affective dysfunction in animal models across species [113,115-117]. While AHN defects 
per se do not cause affective dysfunction [118,119], several anti-depressants increase AHN, and the beneficial effects of fluoxetine on depressive behavior depended at least in part on neurogenesis $[120,121]$. Some widely used antidepressants also induced autophagy in hippocampal neurons [122], and stimulation-induced autophagy in the hippocampus was necessary to form new memories and reverted impaired memory in aged mice [123]. Moreover, trehalose and rapamycin - two strong inducers of autophagy-also exerted anti-depressant-like effects in mice, suggesting that autophagy may have mood-stabilizing effects $[124,125]$. However, these studies did not investigate whether the beneficial effects of autophagy induction on memory and mood involved and required stimulation of AHN.

Mitochondrial dysfunction has been implicated in the development of major depression [126,127] and represents a hallmark of both sporadic and familial forms of PD [63], where depression is a frequent non-motor feature [128]. However, whether mitochondrial defects in the neurogenic niche contribute to, or enhance, stress-induced AHN defects and mood disorders is not known. We addressed this question with PINK1-deficient mice-a model for familial PD—-that display abnormal mitochondrial function in hippocampal NSC and impaired AHN in the DG [58]. Specifically, we investigated whether PINK1 deficiency predisposed mice to basal or stress-induced depression. Mitochondrial and AHN defects in PINK1-deficient alone were insufficient to cause depression $[58,119]$. However, lack of PINK1 exacerbated the stress-induced decline of adult-generated $\mathrm{DCX}^{+}$immature and $\mathrm{NeuN}^{+}$mature neurons in the DG and lowered the threshold for stress-induced depression in mice [119]. Therefore, mitochondrial defects in PD may reduce the resilience to stressinduced depression, a hypothesis worth investigating with additional models. In support of this notion, while chronic stress can cause various mitochondrial deficits [129-132], neither corticosterone nor mild mitochondrial defects alone affected learning [133]. However, their combination resulted in impaired learning, which showed that stress (corticosterone) and mitochondrial defects synergized to precipitate defects of learning [133]. Taken together, these studies suggest that improving mitochondrial function may attenuate or protect against stress-induced AHN defects and depression.

Although autophagy is necessary for adult neurogenesis under physiological conditions $[98,99,101,103]$, pathologically increased autophagy can be detrimental to AHN and may be involved in development of stress-induced cognitive and affective dysfunction. For example, deletion of the autophagy-promoting gene Atg7 abrogated corticosterone-induced death of cultured hippocampal NSPC [134]. Moreover, mice with inducible Atg7 knockout in adult hippocampal NSPC were resilient to chronic stress- and corticosterone-induced deficits of AHN, cognition (spatial memory), and mood (anxiety-like and depressive behaviors) [134]. Therefore, suppressing autophagy may be beneficial for therapeutic intervention in psychological stress-induced disorders [134], although such an approach should be taken cautiously due to the essential function of basal autophagy in most cells and tissues.

\section{Mitochondrial and AHN Defects in Age and Neurodegenerative Disease: Link to Cognitive and Psychiatric Disturbances}

Animal studies support a role of AHN for cognitive flexibility [7-10]. Accordingly, the age-dependent reduction of AHN may contribute to natural cognitive decline. The involvement of mitochondria in this process is not well understood. However, both aging and age-related neurodegenerative disorders are characterized by mitochondrial abnormalities, including accumulation of mitochondrial DNA (mtDNA) mutations, decreased OXPHOS, and increased mitochondrial ROS production [135,136], all of which impair adult neurogenesis [137-139].

With relevance to stem cells, human iPSC derived from tissues of old and young people indicated an age-dependent accumulation of mtDNA damage and a functional mitochondrial decline [140]. Experimentally aging iPSC by continuous propagation also led to abnormal mitochondrial network appearance and mitochondrial gene expression, associated with failure to undergo neuronal differentiation in vitro [141]. Mice with a knockin of mutant mitochondrial DNA polymerase- $\gamma$ (PolgA-mutator mice) had reduced life span and developed premature aging-related phenotypes due to increased accumulation 
of mtDNA mutations [142,143]. Cultured adult NSC from PolgA-mutator mice showed impaired self-renewal and increased mtDNA mutations and ROS production, which led to a reduction of NSC in the SVZ of old PolgA-mutator mice [137]. NSPC from the forebrain of aged wildtype (normal) mice also revealed lower mitochondrial content, respiration rates, and ATP synthase levels compared to young animals [144]. Taken together, these studies show that defects of mitochondria contribute to aging-related impairments of AHN and, therefore, likely also age-related cognitive decline, although the latter notion requires additional experimental support for confirmation.

Mitochondrial dysfunction is also a hallmark of many neurodegenerative disorders including PD [63] and Alzheimer's disease (AD) [145,146], and it has been suggested that impaired AHN may contribute to cognitive and psychiatric disturbances in PD $[147,148]$ and AD [149-152]. While it is difficult to reliably assess neurogenesis in post-mortem brains and few such studies have been carried out to date, reduced numbers of proliferating cells in the SVZ and neural precursor cells in the DG and the OB were reported in postmortem brains of individuals with PD [153]. This finding was replicated in mice by experimental dopamine depletion, which led to the suggestion that dopamine regulates adult SVZ neurogenesis [153]. However, a later study found no difference in the number and proliferation of NSPC between PD subjects and age- and sex-matched controls, nor was SVZ neurogenesis abnormal in five cases with incidental Lewy body disease [154]. Deficits of AHN were also reported in post-mortem brains of $\mathrm{AD}$ patients and individuals with mild cognitive impairment (MCI) [151,152,155]. Increased expression of bone morphogenetic protein 6 in the hippocampus of AD patients correlated with reduced numbers of Sox $2^{+}$ NPC and DCX ${ }^{+}$immature neurons [155]. In a study with 45 patients who died of AD between 52 and 97 years, stereology revealed abnormalities of AHN already in the brain of early-stage AD patients, and the numbers and maturation of $\mathrm{DCX}^{+}$neurons declined progressively with increasing neuropathology (Braak stages) of AD [151]. Nestin ${ }^{+} / \mathrm{Sox}^{+}$ NPC and DCX ${ }^{+}$neuroblasts persisted in the brain of old people, and their numbers were reduced in brains from patients with both $\mathrm{MCI}$ and $\mathrm{AD}$ when compared to age-matched controls [152]. Cognitive performance in MCI patients correlated positively with the number of $\mathrm{DCX}^{+}$neuroblasts, suggesting an association of AHN with cognition [152].

A link between impaired AHN and cognitive and psychiatric disturbances in neurodegeneration is further corroborated by studies in models of PD [58,119,156-160] and AD [161-166]. Although the mechanisms responsible for impaired AHN are pleiotropic, in the case of PINK1-deficient mice, mitochondrial defects in NSPC have been linked to impaired dendritic maturation of $\mathrm{DCX}^{+}$neurons in the DG [58]. In addition, both $\alpha$-Synuclein and amyloid- $\beta(A \beta)$-which form neurotoxic protein aggregates in PD and AD-impair mitochondrial respiration $[145,167]$, suggesting that in transgenic models overexpressing these pathogenic proteins mitochondrial defects also contributed to abnormal AHN $[157,158,165,166]$. Finally, expression of Miro2 - which regulates mitochondrial transport and dynamics and is degraded in a PINK1/Parkin-dependent manner upon induction of mitophagy [168,169], was decreased in Nestin-positive cells of the hippocampus in the 3xTg mouse model of AD [77]. Suppressing Miro2 (by Miro2-siRNA or an Miro2-targeting miRNA) in cultured adult hippocampus-derived NSC of normal mice led to excessive mitochondrial fission, ROS production, and autophagic cell death of NSPC, which was rescued by adenoviral Miro2 over-expression and the Drp1/fission inhibitor Mdivi-1 [77]. Collectively, these studies support the notion that mitochondria-related abnormalities of AHN contribute to cognitive and psychiatric disturbances in neurodegenerative illnesses.

\section{Targeting Mitochondria to Counteract AHN and Cognitive Defects in Old Age and Disease}

Given the critical function of mitochondria throughout adult neurogenesis, targeting mitochondria to improve AHN may be a promising strategy to mitigate age-related cognitive decline and cognitive and psychiatric dysfunctions in neurodegenerative diseases.

Metformin-an FDA-approved drug used for the treatment of type-2 diabetes [170]—shows promise in enhancing adult neurogenesis [171]. Metformin im- 
proved mitochondrial function and was neuroprotective in a model of sporadic PD [172], and it enhanced adult neurogenesis and cognition in models of neuronal dysfunction induced by type- 2 diabetes and ischemia [173-175]. Metformin promotes mitochondrial biogenesis through induction of PGC- $1 \alpha$, a transcriptional coactivator that coordinately induces expression of many mitochondrial metabolism and anti-oxidant genes [172,176,177]. Metformin also stimulates autophagy via AMPK [96]. However, in some studies, the effects of metformin on neurogenesis and cognition were sex-specific [178,179], and in one AD model metformin exacerbated neuropathology and disease phenotypes [180]. Piracetam, which improves mitochondrial bioenergetics and inhibits mitochondrial permeability transition [181], ameliorated aging-associated defects of cultured hippocampal NSPC and increased AHN in old mice [59]. However, piracetam failed to restore AHN in old mice to levels observed in young mice, and whether piracetam-induced AHN improved cognitive performance in aged mice was not investigated [59].

Certain dietary supplements and lifestyle choices have considerable potential to attenuate neuronal dysfunction and enhance neurogenesis through mitochondrial improvement $[45,182]$. NAD ${ }^{+}$acts as a coenzyme in many redox reactions and a co-substrate for metabolism-regulating enzymes including the sirtuins and PARP [182,183]. Sirtuins are deacetylases that mediate the effects of caloric restriction on longevity and adapt cellular metabolism to nutrient availability [184]. Mitochondria-localized sirtuins regulate mitochondrial respiration and signaling, as well as mitochondrial biogenesis through PGC$1 \alpha[182,184,185]$. Supplementation of $\mathrm{NAD}^{+}$, whose levels decline during aging $[183,186]$, improved mitochondrial function [183,187-189] and cognitive performance [190] in animal models of $\mathrm{AD}$ and PD. In contrast, NSPC-specific ablation of the rate-limiting enzyme for $\mathrm{NAD}^{+}$synthesis (Nampt) reduced proliferation of NSPC [186], and conditional deletion of Nampt in forebrain excitatory neurons caused hippocampal and cortical atrophy associated with multiple behavioral and cognitive defects [191]. Exercise also exerts beneficial effects on brain mitochondrial function [192-195]. Exercise-induced AHN improved cognitive function in models of intellectual disability and Alzheimer's disease [161,196,197], as shown previously in normal mice $[17,114,198-200]$. Overall, these studies suggest $\mathrm{NAD}^{+}$ supplementation, activation of specific sirtuins, and exercise as promising strategies to counteract age- and disease-related defects of AHN and cognition.

Influencing the activity of certain signaling pathways and transcription factors that impact on mitochondria may also be explored to enhance adult neurogenesis. The Wnt signaling pathway is important for cell polarity and differentiation, and Wnt-5a has been shown to regulate mitochondrial dynamics and calcium homeostasis in hippocampal neurons [201]. Overexpression of the pro-neural transcription factor Neurod1 in adultborn neurons improved mitochondrial biogenesis and respiration and reversed defects of dendritic growth and spine formation in a mouse model of AD [202]. Finally, an inhibitor of PDE7-by targeting the CAMP/CREB pathway-reversed A $\beta$-induced mitochondrial defects, improved AHN, and rescued cognitive impairments in the APP/PS1 model of $\mathrm{AD}[203]$.

\section{Summary and Concluding Remarks}

Changes of mitochondrial metabolism and structure are not merely secondary adaptations to variable energy demands of different cells along the neurogenic lineage. Instead, mitochondria act as signaling platforms that actively control all stages of neurogenesis, from NSPC fate decisions and proliferation to neuronal differentiation and synaptic integration (Figure 3). The mitochondria-orchestrated program involves stage-specific changes of mitochondrial respiration, biogenesis, dynamics, and ROS production. Mitochondrial fission and ROS-along with ROS produced by NADPH oxidases-tune the activity of specific transcriptional programs (e.g., Nrf2) and cytosolic signaling proteins (e.g., PI3K/Akt, Erk1/2), which is crucial for the earliest NSC fate decisions and transitions from qNSC to IPC by altering the balance between proliferation and differentiation genes, among many others. Once neuroblasts start to differentiate, a coordinated increase of mitochondrial 
biogenesis, fission, and transport ensures that the growing dendrites of newborn neurons are supplied with sufficient mitochondria, which is crucial for dendritic maturation and the survival of newborn neurons. In addition, autophagy-and in particular the selective degradation of damaged mitochondria through mitophagy-is necessary throughout neurogenesis to maintain a healthy cellular mitochondrial network and ROS balance.

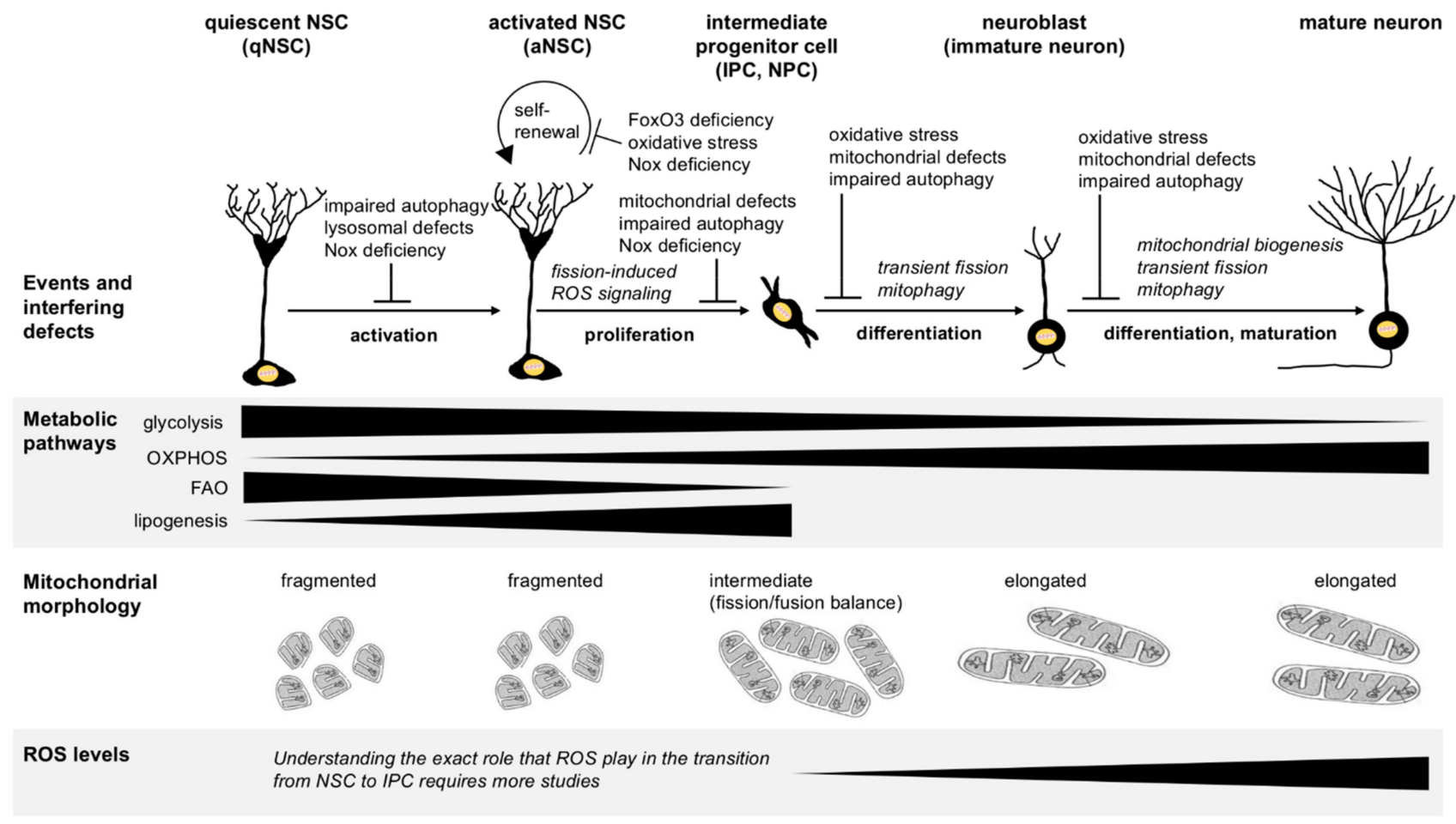

Figure 3. Stage-specific metabolic pathways, mitochondrial dynamics, and ROS regulate cell transition and progression during adult neurogenesis. Neural stem cells (NSC) rely on glycolysis and fatty acid oxidation (FAO) for stemness and self-renewal. An increase of mitochondrial oxidative phosphorylation (OXPHOS) at the expense of FAO and upregulation of de novo lipogenesis in the cytoplasm promote proliferation of NSC and progression toward intermediate progenitor cells (IPC). As IPC begin to differentiate to neuroblasts and further progress to become mature newborn neurons, OXPHOS is crucial to supply the growing cells with sufficient energy. In this phase, mitochondrial biogenesis, fission, and transport are essential to increase mitochondrial content and distribute newly generated mitochondria into the growing and distal branches of maturing dendrites. However, because fragmented mitochondria produce less ATP and fission increases ROS, fission must be transient and followed by fusion. Overall, the mitochondrial morphology changes from fragmented to increasingly elongated during neurogenesis consistent with the progressive reliance of cells on OXPHOS. Reactive oxygen species (ROS) generated by several different NADPH oxidases (Nox proteins) regulate the transition between qNSC and aNSC, NSC renewal, and NSPC proliferation, which has been reviewed elsewhere [79]. In addition, ROS/Nrf2-dependent signaling triggered by mitochondrial fission promotes the transition from aNSC to differentiation-committed IPC. However, the exact role of ROS in this step remains somewhat ambiguous. For more details, please refer to the main text.

Lifestyle choices that improve mitochondrial function and increase neurogenesis such as eating food rich in polyphenols and polyunsaturated fatty acids, regular moderate exercise, or select dietary supplements-all show considerable promise to attenuate age- and disease-related cognitive decline. Beyond that, screening for new drugs that selectively augment mitochondrial function and mitophagy (as opposed to autophagy in general) - perhaps by targeting specific mitochondrial respiratory complexes, chaperones, or mitophagy proteins-may lead to improved treatments for cognitive dysfunction in humans. It will be crucial to test effects of new drug candidates on mitochondrial function, neurogenesis, and cognition both in cell culture (i.e., in vitro differentiation systems) and relevant animal models of disease, including their long-term safety and efficacy in vivo. 
Finally, drug-induced stimulation of mitochondrial metabolism and mitophagy should be moderate-and if possible combined with increasing anti-oxidant responses-as excessive activation of these pathways can cause oxidative stress and mitophagic cell death [204,205]. In this sense, targeting the PGC- $1 \alpha$ master regulator that coordinately increases mitochondrial biogenesis and anti-oxidant gene expression may be particularly promising [206].

Finally, the recognition that metabolism takes center stage in the regulation of NSC function and adult neurogenesis is expected to improve the generation and amplification of patient-derived (autologous, non-immunogenic) iPSC and iPSC-derived neuroblasts and neurons for transplantation into areas of neurodegeneration or the injured brain [207-212]. Conditions that favor glycolysis and fatty acid metabolism should facilitate de-differentiation of adult somatic cells to iPCS and amplification of iPSC, while conditions that suppress glycolysis and induce mitochondrial metabolism should promote efficient differentiation of iPSC to neurons. Increasing the yield of patient-derived iPSC should also facilitate correction of genetic defects by CRISPR/Cas9-mediated gene editing and the characterization of gene-corrected iPSC or iPSC-derived neurons before transplantation.

Funding: This work was supported by a grant from the China National Science Foundation (31970715) to H.B.

Conflicts of Interest: The author declares no conflict of interest.

\section{References}

1. Ming, G.L.; Song, H. Adult neurogenesis in the mammalian brain: Significant answers and significant questions. Neuron 2011, 70, 687-702. [CrossRef]

2. Lepousez, G.; Valley, M.T.; Lledo, P.-M. The Impact of Adult Neurogenesis on Olfactory Bulb Circuits and Computations. Annu. Rev. Physiol. 2013, 75, 339-363. [CrossRef]

3. Lledo, P.M.; Saghatelyan, A. Integrating new neurons into the adult olfactory bulb: Joining the network, life-death decisions, and the effects of sensory experience. Trends Neurosci. 2005, 28, 248-254. [CrossRef]

4. Sun, G.J.; Zhou, Y.; Stadel, R.P.; Moss, J.; Yong, J.H.A.; Ito, S.; Kawasaki, N.K.; Phan, A.T.; Oh, J.H.; Modak, N.; et al. Tangential migration of neuronal precursors of glutamatergic neurons in the adult mammalian brain. Proc. Natl. Acad. Sci. USA 2015, 112, 9484-9489. [CrossRef] [PubMed]

5. Yassa, M.A.; Stark, C.E. Pattern separation in the hippocampus. Trends Neurosci. 2011, 34, 515-525. [CrossRef] [PubMed]

6. Gilbert, P.E.; Kesner, R.P.; Lee, I. Dissociating hippocampal subregions: Double dissociation between dentate gyrus and CA1. Hippocampus 2001, 11, 626-636. [CrossRef] [PubMed]

7. Anacker, C.; Hen, R. Adult hippocampal neurogenesis and cognitive flexibility—Linking memory and mood. Nat. Rev. Neurosci. 2017, 18, 335-346. [CrossRef] [PubMed]

8. Johnston, S.T.; Shtrahman, M.; Parylak, S.; Goncalves, J.T.; Gage, F.H. Paradox of pattern separation and adult neurogenesis: A dual role for new neurons balancing memory resolution and robustness. Neurobiol. Learn. Mem. 2016, 129, 60-68. [CrossRef] [PubMed]

9. Toda, T.; Gage, F.H. Review: Adult neurogenesis contributes to hippocampal plasticity. Cell Tissue Res. 2018, 373, 693-709. [CrossRef] [PubMed]

10. Clelland, C.D.; Choi, M.; Romberg, C.; Clemenson, G.D., Jr.; Fragniere, A.; Tyers, P.; Jessberger, S.; Saksida, L.M.; Barker, R.A.; Gage, F.H.; et al. A functional role for adult hippocampal neurogenesis in spatial pattern separation. Science 2009, 325, 210-213. [CrossRef]

11. Bonafina, A.; Trinchero, M.F.; Rios, A.S.; Bekinschtein, P.; Schinder, A.F.; Paratcha, G.; Ledda, F. GDNF and GFRalpha1 Are Required for Proper Integration of Adult-Born Hippocampal Neurons. Cell Rep. 2019, 29, 4308-4319.e4. [CrossRef]

12. Danielson, N.B.; Kaifosh, P.; Zaremba, J.D.; Lovett-Barron, M.; Tsai, J.; Denny, C.A.; Balough, E.M.; Goldberg, A.R.; Drew, L.J.; Hen, R.; et al. Distinct Contribution of Adult-Born Hippocampal Granule Cells to Context Encoding. Neuron 2016, 90, 101-112. [CrossRef]

13. Kheirbek, M.A.; Tannenholz, L.; Hen, R. NR2B-dependent plasticity of adult-born granule cells is necessary for context discrimination. J. Neurosci. Off. J. Soc. Neurosci. 2012, 32, 8696-8702. [CrossRef]

14. Niibori, Y.; Yu, T.S.; Epp, J.R.; Akers, K.G.; Josselyn, S.A.; Frankland, P.W. Suppression of adult neurogenesis impairs population coding of similar contexts in hippocampal CA3 region. Nat. Commun. 2012, 3, 1253. [CrossRef] [PubMed]

15. Zhuo, J.M.; Tseng, H.A.; Desai, M.; Bucklin, M.E.; Mohammed, A.I.; Robinson, N.T.; Boyden, E.S.; Rangel, L.M.; Jasanoff, A.P.; Gritton, H.J.; et al. Young adult born neurons enhance hippocampal dependent performance via influences on bilateral networks. eLife 2016, 5, e22429. [CrossRef] [PubMed]

16. Creer, D.J.; Romberg, C.; Saksida, L.M.; van Praag, H.; Bussey, T.J. Running enhances spatial pattern separation in mice. Proc. Natl. Acad. Sci. USA 2010, 107, 2367-2372. [CrossRef] [PubMed] 
17. So, J.H.; Huang, C.; Ge, M.; Cai, G.; Zhang, L.; Lu, Y.; Mu, Y. Intense Exercise Promotes Adult Hippocampal Neurogenesis But Not Spatial Discrimination. Front. Cell. Neurosci. 2017, 11, 13. [CrossRef] [PubMed]

18. Sahay, A.; Scobie, K.N.; Hill, A.S.; O'Carroll, C.M.; Kheirbek, M.A.; Burghardt, N.S.; Fenton, A.A.; Dranovsky, A.; Hen, R. Increasing adult hippocampal neurogenesis is sufficient to improve pattern separation. Nature 2011, 472, 466-470. [CrossRef]

19. Eriksson, P.S.; Perfilieva, E.; Bjork-Eriksson, T.; Alborn, A.M.; Nordborg, C.; Peterson, D.A.; Gage, F.H. Neurogenesis in the adult human hippocampus. Nat. Med. 1998, 4, 1313-1317. [CrossRef]

20. Boldrini, M.; Fulmore, C.A.; Tartt, A.N.; Simeon, L.R.; Pavlova, I.; Poposka, V.; Rosoklija, G.B.; Stankov, A.; Arango, V.; Dwork, A.J.; et al. Human Hippocampal Neurogenesis Persists throughout Aging. Cell Stem Cell 2018, 22, 589-599.e5. [CrossRef]

21. Knoth, R.; Singec, I.; Ditter, M.; Pantazis, G.; Capetian, P.; Meyer, R.P.; Horvat, V.; Volk, B.; Kempermann, G. Murine features of neurogenesis in the human hippocampus across the lifespan from 0 to 100 years. PLoS ONE 2010, 5, e8809.

22. Sorrells, S.F.; Paredes, M.F.; Cebrian-Silla, A.; Sandoval, K.; Qi, D.; Kelley, K.W.; James, D.; Mayer, S.; Chang, J.; Auguste, K.I.; et al. Human hippocampal neurogenesis drops sharply in children to undetectable levels in adults. Nature 2018, 555, 377-381. [CrossRef]

23. Charvet, C.J.; Finlay, B.L. Comparing Adult Hippocampal Neurogenesis across Species: Translating Time to Predict the Tempo in Humans. Front. Neurosci. 2018, 12, 706. [CrossRef]

24. Snyder, J.S.; Cameron, H.A. Could adult hippocampal neurogenesis be relevant for human behavior? Behav. Brain Res. 2012, 227, 384-390. [CrossRef]

25. Snyder, J.S. Recalibrating the Relevance of Adult Neurogenesis. Trends Neurosci. 2019, 42, 164-178. [CrossRef] [PubMed]

26. Lee, H.; Thuret, S. Adult Human Hippocampal Neurogenesis: Controversy and Evidence. Trends Mol. Med. 2018, 24, 521-522. [CrossRef]

27. Kempermann, G.; Gage, F.H.; Aigner, L.; Song, H.; Curtis, M.A.; Thuret, S.; Kuhn, H.G.; Jessberger, S.; Frankland, P.W.; Cameron, H.A.; et al. Human Adult Neurogenesis: Evidence and Remaining Questions. Cell Stem Cell 2018, 23, 25-30. [CrossRef]

28. Paredes, M.F.; Sorrells, S.F.; Cebrian-Silla, A.; Sandoval, K.; Qi, D.; Kelley, K.W.; James, D.; Mayer, S.; Chang, J.; Auguste, K.I.; et al. Does Adult Neurogenesis Persist in the Human Hippocampus? Cell Stem Cell 2018, 23, 780-781. [CrossRef]

29. Tartt, A.N.; Fulmore, C.A.; Liu, Y.; Rosoklija, G.B.; Dwork, A.J.; Arango, V.; Hen, R.; Mann, J.J.; Boldrini, M. Considerations for Assessing the Extent of Hippocampal Neurogenesis in the Adult and Aging Human Brain. Cell Stem Cell 2018, 23, 782-783. [CrossRef]

30. Bond, A.M.; Ming, G.L.; Song, H. Adult Mammalian Neural Stem Cells and Neurogenesis: Five Decades Later. Cell Stem Cell 2015, 17, 385-395. [CrossRef] [PubMed]

31. Aimone, J.B.; Li, Y.; Lee, S.W.; Clemenson, G.D.; Deng, W.; Gage, F.H. Regulation and function of adult neurogenesis: From genes to cognition. Physiol. Rev. 2014, 94, 991-1026. [CrossRef]

32. Mitra, K. Mitochondrial fission-fusion as an emerging key regulator of cell proliferation and differentiation. Bioessays News Rev. Mol. Cell. Dev. Biol. 2013, 35, 955-964. [CrossRef] [PubMed]

33. Agathocleous, M.; Harris, W.A. Metabolism in physiological cell proliferation and differentiation. Trends Cell Biol. 2013, 23, 484-492. [CrossRef] [PubMed]

34. Detmer, S.A.; Chan, D.C. Functions and dysfunctions of mitochondrial dynamics. Nat. Rev. Mol. Cell Biol. 2007, 8, 870-879. [CrossRef]

35. Maryanovich, M.; Zaltsman, Y.; Ruggiero, A.; Goldman, A.; Shachnai, L.; Zaidman, S.L.; Porat, Z.; Golan, K.; Lapidot, T.; Gross, A. An MTCH2 pathway repressing mitochondria metabolism regulates haematopoietic stem cell fate. Nat. Commun. 2015, 6, 7901. [CrossRef] [PubMed]

36. Orogo, A.M.; Gonzalez, E.R.; Kubli, D.A.; Baptista, I.L.; Ong, S.B.; Prolla, T.A.; Sussman, M.A.; Murphy, A.N.; Gustafsson, A.B. Accumulation of Mitochondrial DNA Mutations Disrupts Cardiac Progenitor Cell Function and Reduces Survival. J. Biol. Chem. 2015, 290, 22061-22075. [CrossRef]

37. Takubo, K.; Nagamatsu, G.; Kobayashi, C.I.; Nakamura-Ishizu, A.; Kobayashi, H.; Ikeda, E.; Goda, N.; Rahimi, Y.; Johnson, R.S.; Soga, T.; et al. Regulation of glycolysis by Pdk functions as a metabolic checkpoint for cell cycle quiescence in hematopoietic stem cells. Cell Stem Cell 2013, 12, 49-61. [CrossRef]

38. Gaspar, J.A.; Doss, M.X.; Hengstler, J.G.; Cadenas, C.; Hescheler, J.; Sachinidis, A. Unique metabolic features of stem cells, cardiomyocytes, and their progenitors. Circ. Res. 2014, 114, 1346-1360. [CrossRef]

39. Shyh-Chang, N.; Daley, G.Q.; Cantley, L.C. Stem cell metabolism in tissue development and aging. Development 2013, 140, 2535-2547. [CrossRef]

40. Chen, C.T.; Shih, Y.R.; Kuo, T.K.; Lee, O.K.; Wei, Y.H. Coordinated changes of mitochondrial biogenesis and antioxidant enzymes during osteogenic differentiation of human mesenchymal stem cells. Stem Cells 2008, 26, 960-968. [CrossRef]

41. Prigione, A.; Fauler, B.; Lurz, R.; Lehrach, H.; Adjaye, J. The senescence-related mitochondrial/oxidative stress pathway is repressed in human induced pluripotent stem cells. Stem Cells 2010, 28, 721-733. [CrossRef]

42. Folmes, C.D.; Nelson, T.J.; Martinez-Fernandez, A.; Arrell, D.K.; Lindor, J.Z.; Dzeja, P.P.; Ikeda, Y.; Perez-Terzic, C.; Terzic, A. Somatic oxidative bioenergetics transitions into pluripotency-dependent glycolysis to facilitate nuclear reprogramming. Cell Metab. 2011, 14, 264-271. [CrossRef]

43. Xu, X.; Duan, S.; Yi, F.; Ocampo, A.; Liu, G.H.; Izpisua Belmonte, J.C. Mitochondrial regulation in pluripotent stem cells. Cell Metab. 2013, 18, 325-332. [CrossRef] 
44. Zheng, X.; Boyer, L.; Jin, M.; Mertens, J.; Kim, Y.; Ma, L.; Ma, L.; Hamm, M.; Gage, F.H.; Hunter, T. Metabolic reprogramming during neuronal differentiation from aerobic glycolysis to neuronal oxidative phosphorylation. eLife 2016, 5, e13374. [CrossRef]

45. Valente, T.; Hidalgo, J.; Bolea, I.; Ramirez, B.; Angles, N.; Reguant, J.; Morello, J.R.; Gutierrez, C.; Boada, M.; Unzeta, M. A diet enriched in polyphenols and polyunsaturated fatty acids, LMN diet, induces neurogenesis in the subventricular zone and hippocampus of adult mouse brain. J. Alzheimer's Dis. 2009, 18, 849-865. [CrossRef]

46. Knobloch, M.; Braun, S.M.; Zurkirchen, L.; von Schoultz, C.; Zamboni, N.; Arauzo-Bravo, M.J.; Kovacs, W.J.; Karalay, O.; Suter, U.; Machado, R.A.; et al. Metabolic control of adult neural stem cell activity by Fasn-dependent lipogenesis. Nature 2013, 493, 226-230. [CrossRef] [PubMed]

47. Chorna, N.E.; Santos-Soto, I.J.; Carballeira, N.M.; Morales, J.L.; de la Nuez, J.; Catala-Valentin, A.; Chornyy, A.P.; Vazquez-Montes, A.; De Ortiz, S.P. Fatty acid synthase as a factor required for exercise-induced cognitive enhancement and dentate gyrus cellular proliferation. PLoS ONE 2013, 8, e77845. [CrossRef] [PubMed]

48. Schnell, A.; Chappuis, S.; Schmutz, I.; Brai, E.; Ripperger, J.A.; Schaad, O.; Welzl, H.; Descombes, P.; Alberi, L.; Albrecht, U. The nuclear receptor REV-ERBalpha regulates Fabp7 and modulates adult hippocampal neurogenesis. PLoS ONE 2014, 9, e99883. [CrossRef] [PubMed]

49. Bowers, M.; Liang, T.; Gonzalez-Bohorquez, D.; Zocher, S.; Jaeger, B.N.; Kovacs, W.J.; Rohrl, C.; Cramb, K.M.L.; Winterer, J.; Kruse, M.; et al. FASN-Dependent Lipid Metabolism Links Neurogenic Stem/Progenitor Cell Activity to Learning and Memory Deficits. Cell Stem Cell 2020, 27, 98-109.e11. [CrossRef] [PubMed]

50. Stoll, E.A.; Makin, R.; Sweet, I.R.; Trevelyan, A.J.; Miwa, S.; Horner, P.J.; Turnbull, D.M. Neural Stem Cells in the Adult Subventricular Zone Oxidize Fatty Acids to Produce Energy and Support Neurogenic Activity. Stem Cells 2015, 33, 2306-2319. [CrossRef]

51. Knobloch, M.; Pilz, G.A.; Ghesquiere, B.; Kovacs, W.J.; Wegleiter, T.; Moore, D.L.; Hruzova, M.; Zamboni, N.; Carmeliet, P.; Jessberger, S. A Fatty Acid Oxidation-Dependent Metabolic Shift Regulates Adult Neural Stem Cell Activity. Cell Rep. 2017, 20, 2144-2155. [CrossRef] [PubMed]

52. Knobloch, M. The Role of Lipid Metabolism for Neural Stem Cell Regulation. Brain Plast. 2017, 3, 61-71. [CrossRef]

53. Chandel, N.S. Mitochondria as signaling organelles. BMC Biol. 2014, 12, 34. [CrossRef]

54. Ma, K.; Chen, G.; Li, W.; Kepp, O.; Zhu, Y.; Chen, Q. Mitophagy, Mitochondrial Homeostasis, and Cell Fate. Front. Cell Dev. Biol. 2020, 8, 467. [CrossRef]

55. Palikaras, K.; Lionaki, E.; Tavernarakis, N. Mechanisms of mitophagy in cellular homeostasis, physiology and pathology. Nat. Cell Biol. 2018, 20, 1013-1022.

56. Shin, J.; Berg, D.A.; Zhu, Y.; Shin, J.Y.; Song, J.; Bonaguidi, M.A.; Enikolopov, G.; Nauen, D.W.; Christian, K.M.; Ming, G.L.; et al. Single-Cell RNA-Seq with Waterfall Reveals Molecular Cascades underlying Adult Neurogenesis. Cell Stem Cell 2015, 17, 360-372. [CrossRef]

57. Diaz-Castro, B.; Pardal, R.; Garcia-Flores, P.; Sobrino, V.; Duran, R.; Piruat, J.I.; Lopez-Barneo, J. Resistance of glia-like central and peripheral neural stem cells to genetically induced mitochondrial dysfunction-differential effects on neurogenesis. EMBO Rep. 2015, 16, 1511-1519. [CrossRef] [PubMed]

58. Agnihotri, S.K.; Shen, R.; Li, J.; Gao, X.; Bueler, H. Loss of PINK1 leads to metabolic deficits in adult neural stem cells and impedes differentiation of newborn neurons in the mouse hippocampus. Faseb J. Off. Publ. Fed. Am. Soc. Exp. Biol. 2017, 31, $2839-2853$. [CrossRef] [PubMed]

59. Beckervordersandforth, R.; Ebert, B.; Schaffner, I.; Moss, J.; Fiebig, C.; Shin, J.; Moore, D.L.; Ghosh, L.; Trinchero, M.F.; Stockburger, C.; et al. Role of Mitochondrial Metabolism in the Control of Early Lineage Progression and Aging Phenotypes in Adult Hippocampal Neurogenesis. Neuron 2017, 93, 560-573.e6. [CrossRef]

60. Cabello-Rivera, D.; Sarmiento-Soto, H.; Lopez-Barneo, J.; Munoz-Cabello, A.M. Mitochondrial Complex I Function Is Essential for Neural Stem/Progenitor Cells Proliferation and Differentiation. Front. Neurosci. 2019, 13, 664. [CrossRef]

61. Ekstrand, M.I.; Terzioglu, M.; Galter, D.; Zhu, S.; Hofstetter, C.; Lindqvist, E.; Thams, S.; Bergstrand, A.; Hansson, F.S.; Trifunovic, A.; et al. Progressive parkinsonism in mice with respiratory-chain-deficient dopamine neurons. Proc. Natl. Acad. Sci. USA 2007, 104, 1325-1330. [CrossRef]

62. Akundi, R.S.; Huang, Z.; Eason, J.; Pandya, J.D.; Zhi, L.; Cass, W.A.; Sullivan, P.G.; Bueler, H. Increased mitochondrial calcium sensitivity and abnormal expression of innate immunity genes precede dopaminergic defects in Pink1-deficient mice. PLoS ONE 2011, 6, e16038. [CrossRef] [PubMed]

63. Bueler, H. Impaired mitochondrial dynamics and function in the pathogenesis of Parkinson's disease. Exp. Neurol. 2009, 218, 235-246. [CrossRef] [PubMed]

64. Wakabayashi, J.; Zhang, Z.; Wakabayashi, N.; Tamura, Y.; Fukaya, M.; Kensler, T.W.; Iijima, M.; Sesaki, H. The dynamin-related GTPase Drp1 is required for embryonic and brain development in mice. J. Cell Biol. 2009, 186, 805-816. [CrossRef] [PubMed]

65. Ishihara, N.; Nomura, M.; Jofuku, A.; Kato, H.; Suzuki, S.O.; Masuda, K.; Otera, H.; Nakanishi, Y.; Nonaka, I.; Goto, Y.; et al. Mitochondrial fission factor Drp1 is essential for embryonic development and synapse formation in mice. Nat. Cell Biol. 2009, 11, 958-966. [CrossRef]

66. Steib, K.; Schaffner, I.; Jagasia, R.; Ebert, B.; Lie, D.C. Mitochondria modify exercise-induced development of stem cell-derived neurons in the adult brain. J. Neurosci. Off. J. Soc. Neurosci. 2014, 34, 6624-6633. [CrossRef] 
67. Lopez-Domenech, G.; Higgs, N.F.; Vaccaro, V.; Ros, H.; Arancibia-Carcamo, I.L.; MacAskill, A.F.; Kittler, J.T. Loss of Dendritic Complexity Precedes Neurodegeneration in a Mouse Model with Disrupted Mitochondrial Distribution in Mature Dendrites. Cell Rep. 2016, 17, 317-327. [CrossRef]

68. Pickrell, A.M.; Youle, R.J. The roles of PINK1, parkin, and mitochondrial fidelity in Parkinson's disease. Neuron 2015, 85, 257-273. [CrossRef]

69. Akundi, R.S.; Zhi, L.; Sullivan, P.G.; Bueler, H. Shared and cell type-specific mitochondrial defects and metabolic adaptations in primary cells from PINK1-deficient mice. Neuro-Degener. Dis. 2013, 12, 136-149. [CrossRef]

70. Poole, A.C.; Thomas, R.E.; Andrews, L.A.; McBride, H.M.; Whitworth, A.J.; Pallanck, L.J. The PINK1/Parkin pathway regulates mitochondrial morphology. Proc. Natl. Acad. Sci. USA 2008, 105, 1638-1643. [CrossRef]

71. Yu, W.; Sun, Y.; Guo, S.; Lu, B. The PINK1/Parkin pathway regulates mitochondrial dynamics and function in mammalian hippocampal and dopaminergic neurons. Hum. Mol. Genet. 2011, 20, 3227-3240. [CrossRef]

72. Khacho, M.; Clark, A.; Svoboda, D.S.; Azzi, J.; MacLaurin, J.G.; Meghaizel, C.; Sesaki, H.; Lagace, D.C.; Germain, M.; Harper, M.E.; et al. Mitochondrial Dynamics Impacts Stem Cell Identity and Fate Decisions by Regulating a Nuclear Transcriptional Program. Cell Stem Cell 2016, 19, 232-247. [CrossRef]

73. Furutachi, S.; Miya, H.; Watanabe, T.; Kawai, H.; Yamasaki, N.; Harada, Y.; Imayoshi, I.; Nelson, M.; Nakayama, K.I.; Hirabayashi, Y.; et al. Slowly dividing neural progenitors are an embryonic origin of adult neural stem cells. Nat. Neurosci. 2015, 18, 657-665. [CrossRef]

74. Fuentealba, L.C.; Rompani, S.B.; Parraguez, J.I.; Obernier, K.; Romero, R.; Cepko, C.L.; Alvarez-Buylla, A. Embryonic Origin of Postnatal Neural Stem Cells. Cell 2015, 161, 1644-1655. [CrossRef]

75. Khacho, M.; Clark, A.; Svoboda, D.S.; MacLaurin, J.G.; Lagace, D.C.; Park, D.S.; Slack, R.S. Mitochondrial dysfunction underlies cognitive defects as a result of neural stem cell depletion and impaired neurogenesis. Hum. Mol. Genet. 2017, 26, 3327-3341. [CrossRef] [PubMed]

76. Kim, H.J.; Shaker, M.R.; Cho, B.; Cho, H.M.; Kim, H.; Kim, J.Y.; Sun, W. Dynamin-related protein 1 controls the migration and neuronal differentiation of subventricular zone-derived neural progenitor cells. Sci. Rep. 2015, 5, 15962. [CrossRef] [PubMed]

77. Woo, H.N.; Park, S.; Kim, H.L.; Jung, M.K.; Pack, C.G.; Park, J.; Cho, Y.; Jo, D.G.; Kim, D.K.; Mook-Jung, I.; et al. miR-351-5p/Miro2 axis contributes to hippocampal neural progenitor cell death via unbalanced mitochondrial fission. Mol. Ther. Nucleic Acids 2021, 23, 643-656. [CrossRef] [PubMed]

78. Agarwal, S.; Yadav, A.; Tiwari, S.K.; Seth, B.; Chauhan, L.K.; Khare, P.; Ray, R.S.; Chaturvedi, R.K. Dynamin-related Protein 1 Inhibition Mitigates Bisphenol A-mediated Alterations in Mitochondrial Dynamics and Neural Stem Cell Proliferation and Differentiation. J. Biol. Chem. 2016, 291, 15923-15939. [CrossRef] [PubMed]

79. Terzi, A.; Suter, D.M. The role of NADPH oxidases in neuronal development. Free Radic. Biol. Med. 2020, 154, 33-47. [CrossRef] [PubMed]

80. Iqbal, M.A.; Eftekharpour, E. Regulatory Role of Redox Balance in Determination of Neural Precursor Cell Fate. Stem Cells Int. 2017, 2017, 9209127. [CrossRef]

81. Maryanovich, M.; Gross, A. A ROS rheostat for cell fate regulation. Trends Cell Biol. 2013, 23, 129-134. [CrossRef]

82. Prozorovski, T.; Schneider, R.; Berndt, C.; Hartung, H.P.; Aktas, O. Redox-regulated fate of neural stem progenitor cells. Biochim. Biophys. Acta 2015, 1850, 1543-1554. [CrossRef] [PubMed]

83. Wilson, C.; Munoz-Palma, E.; Gonzalez-Billault, C. From birth to death: A role for reactive oxygen species in neuronal development. Semin. Cell Dev. Biol. 2018, 80, 43-49. [CrossRef] [PubMed]

84. Yuan, T.F.; Gu, S.; Shan, C.; Marchado, S.; Arias-Carrion, O. Oxidative Stress and Adult Neurogenesis. Stem Cell Rev. Rep. 2015, 11, 706-709. [CrossRef] [PubMed]

85. Bose, A.; Beal, M.F. Mitochondrial dysfunction and oxidative stress in induced pluripotent stem cell models of Parkinson's disease. Eur. J. Neurosci. 2019, 49, 525-532. [CrossRef]

86. Walton, N.M.; Shin, R.; Tajinda, K.; Heusner, C.L.; Kogan, J.H.; Miyake, S.; Chen, Q.; Tamura, K.; Matsumoto, M. Adult neurogenesis transiently generates oxidative stress. PLoS ONE 2012, 7, e35264. [CrossRef] [PubMed]

87. Adusumilli, V.S.; Walker, T.L.; Overall, R.W.; Klatt, G.M.; Zeidan, S.A.; Zocher, S.; Kirova, D.G.; Ntitsias, K.; Fischer, T.J.; Sykes, A.M.; et al. ROS Dynamics Delineate Functional States of Hippocampal Neural Stem Cells and Link to Their Activity-Dependent Exit from Quiescence. Cell Stem Cell 2020, 28, 300-314.e6.

88. Wang, J.; Ma, M.W.; Dhandapani, K.M.; Brann, D.W. NADPH oxidase 2 deletion enhances neurogenesis following traumatic brain injury. Free Radic. Biol. Med. 2018, 123, 62-71. [CrossRef]

89. Ali, A.A.H.; Schwarz-Herzke, B.; Mir, S.; Sahlender, B.; Victor, M.; Gorg, B.; Schmuck, M.; Dach, K.; Fritsche, E.; Kremer, A.; et al. Deficiency of the clock gene Bmal1 affects neural progenitor cell migration. Brain Struct. Funct. 2019, 224, 373-386. [CrossRef]

90. Karkkainen, V.; Pomeshchik, Y.; Savchenko, E.; Dhungana, H.; Kurronen, A.; Lehtonen, S.; Naumenko, N.; Tavi, P.; Levonen, A.L.; Yamamoto, M.; et al. Nrf2 regulates neurogenesis and protects neural progenitor cells against Abeta toxicity. Stem Cells 2014, 32, 1904-1916. [CrossRef]

91. Rharass, T.; Lantow, M.; Gbankoto, A.; Weiss, D.G.; Panakova, D.; Lucas, S. Ascorbic acid alters cell fate commitment of human neural progenitors in a WNT/beta-catenin/ROS signaling dependent manner. J. Biomed. Sci. 2017, 24, 78. [CrossRef] [PubMed] 
92. Forsberg, K.; Wuttke, A.; Quadrato, G.; Chumakov, P.M.; Wizenmann, A.; Di Giovanni, S. The tumor suppressor p53 fine-tunes reactive oxygen species levels and neurogenesis via PI3 kinase signaling. J. Neurosci. Off. J. Soc. Neurosci. 2013, 33, 14318-14330. [CrossRef] [PubMed]

93. Le Belle, J.E.; Orozco, N.M.; Paucar, A.A.; Saxe, J.P.; Mottahedeh, J.; Pyle, A.D.; Wu, H.; Kornblum, H.I. Proliferative neural stem cells have high endogenous ROS levels that regulate self-renewal and neurogenesis in a PI3K/Akt-dependant manner. Cell Stem Cell 2011, 8, 59-71. [CrossRef]

94. Zhang, L.; Wang, G.; Chen, X.; Xue, X.; Guo, Q.; Liu, M.; Zhao, J. Formyl peptide receptors promotes neural differentiation in mouse neural stem cells by ROS generation and regulation of PI3K-AKT signaling. Sci. Rep. 2017, 7, 206. [CrossRef]

95. Hou, Y.; Ouyang, X.; Wan, R.; Cheng, H.; Mattson, M.P.; Cheng, A. Mitochondrial superoxide production negatively regulates neural progenitor proliferation and cerebral cortical development. Stem Cells 2012, 30, 2535-2547. [CrossRef] [PubMed]

96. Leidal, A.M.; Levine, B.; Debnath, J. Autophagy and the cell biology of age-related disease. Nat. Cell Biol. 2018, 20, 1338-1348. [CrossRef] [PubMed]

97. Yazdankhah, M.; Farioli-Vecchioli, S.; Tonchev, A.B.; Stoykova, A.; Cecconi, F. The autophagy regulators Ambra1 and Beclin 1 are required for adult neurogenesis in the brain subventricular zone. Cell Death Dis. 2014, 5, e1403. [CrossRef] [PubMed]

98. Xi, Y.; Dhaliwal, J.S.; Ceizar, M.; Vaculik, M.; Kumar, K.L.; Lagace, D.C. Knockout of Atg5 delays the maturation and reduces the survival of adult-generated neurons in the hippocampus. Cell Death Dis. 2016, 7, e2127. [CrossRef]

99. Petri, R.; Pircs, K.; Jonsson, M.E.; Akerblom, M.; Brattas, P.L.; Klussendorf, T.; Jakobsson, J. let-7 regulates radial migration of new-born neurons through positive regulation of autophagy. EMBO J. 2017, 36, 1379-1391. [CrossRef]

100. Paik, J.H.; Ding, Z.; Narurkar, R.; Ramkissoon, S.; Muller, F.; Kamoun, W.S.; Chae, S.S.; Zheng, H.; Ying, H.; Mahoney, J.; et al. FoxOs cooperatively regulate diverse pathways governing neural stem cell homeostasis. Cell Stem Cell 2009, 5, 540-553. [CrossRef]

101. Schaffner, I.; Minakaki, G.; Khan, M.A.; Balta, E.A.; Schlotzer-Schrehardt, U.; Schwarz, T.J.; Beckervordersandforth, R.; Winner, B.; Webb, A.E.; DePinho, R.A.; et al. FoxO Function Is Essential for Maintenance of Autophagic Flux and Neuronal Morphogenesis in Adult Neurogenesis. Neuron 2018, 99, 1188-1203e6. [CrossRef] [PubMed]

102. Renault, V.M.; Rafalski, V.A.; Morgan, A.A.; Salih, D.A.; Brett, J.O.; Webb, A.E.; Villeda, S.A.; Thekkat, P.U.; Guillerey, C.; Denko, N.C.; et al. FoxO3 regulates neural stem cell homeostasis. Cell Stem Cell 2009, 5, 527-539. [CrossRef] [PubMed]

103. Audesse, A.J.; Dhakal, S.; Hassell, L.A.; Gardell, Z.; Nemtsova, Y.; Webb, A.E. FOXO3 directly regulates an autophagy network to functionally regulate proteostasis in adult neural stem cells. PLoS Genet. 2019, 15, e1008097. [CrossRef] [PubMed]

104. Cairns, G.; Thumiah-Mootoo, M.; Burelle, Y.; Khacho, M. Mitophagy: A New Player in Stem Cell Biology. Biology 2020,9 , 481. [CrossRef] [PubMed]

105. Leeman, D.S.; Hebestreit, K.; Ruetz, T.; Webb, A.E.; McKay, A.; Pollina, E.A.; Dulken, B.W.; Zhao, X.; Yeo, R.W.; Ho, T.T.; et al. Lysosome activation clears aggregates and enhances quiescent neural stem cell activation during aging. Science 2018, 359, 1277-1283. [CrossRef] [PubMed]

106. Snyder, J.S.; Soumier, A.; Brewer, M.; Pickel, J.; Cameron, H.A. Adult hippocampal neurogenesis buffers stress responses and depressive behaviour. Nature 2011, 476, 458-461. [CrossRef]

107. Eliwa, H.; Brizard, B.; Le Guisquet, A.M.; Hen, R.; Belzung, C.; Surget, A. Adult neurogenesis augmentation attenuates anhedonia and HPA axis dysregulation in a mouse model of chronic stress and depression. Psychoneuroendocrinology 2020, 124, 105097. [CrossRef]

108. Anacker, C.; Luna, V.M.; Stevens, G.S.; Millette, A.; Shores, R.; Jimenez, J.C.; Chen, B.; Hen, R. Hippocampal neurogenesis confers stress resilience by inhibiting the ventral dentate gyrus. Nature 2018, 559, 98-102. [CrossRef]

109. Levone, B.R.; Cryan, J.F.; O'Leary, O.F. Role of adult hippocampal neurogenesis in stress resilience. Neurobiol. Stress 2015, 1, 147-155. [CrossRef]

110. Yun, S.; Reynolds, R.P.; Masiulis, I.; Eisch, A.J. Re-evaluating the link between neuropsychiatric disorders and dysregulated adult neurogenesis. Nat. Med. 2016, 22, 1239-1247. [CrossRef]

111. Jacobson, L.; Sapolsky, R. The role of the hippocampus in feedback regulation of the hypothalamic-pituitary-adrenocortical axis. Endocr. Rev. 1991, 12, 118-134. [CrossRef] [PubMed]

112. McEwen, B.S. Physiology and neurobiology of stress and adaptation: Central role of the brain. Physiol. Rev. 2007, 87, 873-904. [CrossRef] [PubMed]

113. Gould, E.; Tanapat, P.; McEwen, B.S.; Flugge, G.; Fuchs, E. Proliferation of granule cell precursors in the dentate gyrus of adult monkeys is diminished by stress. Proc. Natl. Acad. Sci. USA 1998, 95, 3168-3171. [CrossRef]

114. Opendak, M.; Gould, E. Adult neurogenesis: A substrate for experience-dependent change. Trends Cogn. Sci. 2015, 19, 151-161. [CrossRef] [PubMed]

115. Murray, F.; Smith, D.W.; Hutson, P.H. Chronic low dose corticosterone exposure decreased hippocampal cell proliferation, volume and induced anxiety and depression like behaviours in mice. Eur. J. Pharmacol. 2008, 583, 115-127. [CrossRef]

116. Perera, T.D.; Dwork, A.J.; Keegan, K.A.; Thirumangalakudi, L.; Lipira, C.M.; Joyce, N.; Lange, C.; Higley, J.D.; Rosoklija, G.; Hen, R.; et al. Necessity of hippocampal neurogenesis for the therapeutic action of antidepressants in adult nonhuman primates. PLoS ONE 2011, 6, e17600. [CrossRef]

117. Hayashi, Y.; Jinnou, H.; Sawamoto, K.; Hitoshi, S. Adult neurogenesis and its role in brain injury and psychiatric diseases. J. Neurochem. 2018. [CrossRef] 
118. Miller, B.R.; Hen, R. The current state of the neurogenic theory of depression and anxiety. Curr. Opin. Neurobiol. 2015, 30, 51-58. [CrossRef]

119. Agnihotri, S.K.; Sun, L.; Yee, B.K.; Shen, R.; Akundi, R.S.; Zhi, L.; Duncan, M.J.; Cass, W.A.; Bueler, H. PINK1 deficiency is associated with increased deficits of adult hippocampal neurogenesis and lowers the threshold for stress-induced depression in mice. Behav. Brain Res. 2019, 363, 161-172. [CrossRef]

120. David, D.J.; Samuels, B.A.; Rainer, Q.; Wang, J.W.; Marsteller, D.; Mendez, I.; Drew, M.; Craig, D.A.; Guiard, B.P.; Guilloux, J.P.; et al. Neurogenesis-dependent and -independent effects of fluoxetine in an animal model of anxiety/depression. Neuron 2009, 62, 479-493. [CrossRef]

121. Perera, T.D.; Coplan, J.D.; Lisanby, S.H.; Lipira, C.M.; Arif, M.; Carpio, C.; Spitzer, G.; Santarelli, L.; Scharf, B.; Hen, R.; et al. Antidepressant-induced neurogenesis in the hippocampus of adult nonhuman primates. J. Neurosci. Off. J. Soc. Neurosci. 2007, 27, 4894-4901. [CrossRef] [PubMed]

122. Gulbins, A.; Schumacher, F.; Becker, K.A.; Wilker, B.; Soddemann, M.; Boldrin, F.; Muller, C.P.; Edwards, M.J.; Goodman, M.; Caldwell, C.C.; et al. Antidepressants act by inducing autophagy controlled by sphingomyelin-ceramide. Mol. Psychiatry 2018, 23 , 2324-2346. [CrossRef] [PubMed]

123. Glatigny, M.; Moriceau, S.; Rivagorda, M.; Ramos-Brossier, M.; Nascimbeni, A.C.; Lante, F.; Shanley, M.R.; Boudarene, N.; Rousseaud, A.; Friedman, A.K.; et al. Autophagy Is Required for Memory Formation and Reverses Age-Related Memory Decline. Curr. Biol. Cb 2019, 29, 435-448.e8. [CrossRef] [PubMed]

124. Kara, N.Z.; Flaisher-Grinberg, S.; Anderson, G.W.; Agam, G.; Einat, H. Mood-stabilizing effects of rapamycin and its analog temsirolimus: Relevance to autophagy. Behav. Pharmacol. 2018, 29, 379-384. [CrossRef]

125. Kara, N.Z.; Toker, L.; Agam, G.; Anderson, G.W.; Belmaker, R.H.; Einat, H. Trehalose induced antidepressant-like effects and autophagy enhancement in mice. Psychopharmacology 2013, 229, 367-375. [CrossRef]

126. Allen, J.; Romay-Tallon, R.; Brymer, K.J.; Caruncho, H.J.; Kalynchuk, L.E. Mitochondria and Mood: Mitochondrial Dysfunction as a Key Player in the Manifestation of Depression. Front. Neurosci. 2018, 12, 386. [CrossRef]

127. Fattal, O.; Budur, K.; Vaughan, A.J.; Franco, K. Review of the literature on major mental disorders in adult patients with mitochondrial diseases. Psychosomatics 2006, 47, 1-7. [CrossRef] [PubMed]

128. Schapira, A.H.V.; Chaudhuri, K.R.; Jenner, P. Non-motor features of Parkinson disease. Nat. Rev. Neurosci. 2017, 18, 435-450. [CrossRef]

129. Liu, W.; Zhou, C. Corticosterone reduces brain mitochondrial function and expression of mitofusin, BDNF in depression-like rodents regardless of exercise preconditioning. Psychoneuroendocrinology 2012, 37, 1057-1070. [CrossRef]

130. Seo, J.S.; Lee, K.W.; Kim, T.K.; Baek, I.S.; Im, J.Y.; Han, P.L. Behavioral stress causes mitochondrial dysfunction via ABAD up-regulation and aggravates plaque pathology in the brain of a mouse model of Alzheimer disease. Free Radic. Biol. Med. 2011, 50, 1526-1535. [CrossRef]

131. Yu, J.; Yu, B.; He, J.; Zheng, P.; Mao, X.; Han, G.; Chen, D. Chronic glucocorticoid exposure-induced epididymal adiposity is associated with mitochondrial dysfunction in white adipose tissue of male C57BL/6J mice. PLoS ONE 2014, 9, e112628. [CrossRef]

132. Choi, G.E.; Oh, J.Y.; Lee, H.J.; Chae, C.W.; Kim, J.S.; Jung, Y.H.; Han, H.J. Glucocorticoid-mediated ER-mitochondria contacts reduce AMPA receptor and mitochondria trafficking into cell terminus via microtubule destabilization. Cell Death Dis. 2018, 9 , 1137. [CrossRef] [PubMed]

133. Bennett, M.C.; Mlady, G.W.; Fleshner, M.; Rose, G.M. Synergy between chronic corticosterone and sodium azide treatments in producing a spatial learning deficit and inhibiting cytochrome oxidase activity. Proc. Natl. Acad. Sci. USA 1996, 93, 1330-1334. [CrossRef] [PubMed]

134. Jung, S.; Choe, S.; Woo, H.; Jeong, H.; An, H.K.; Moon, H.; Ryu, H.Y.; Yeo, B.K.; Lee, Y.W.; Choi, H.; et al. Autophagic death of neural stem cells mediates chronic stress-induced decline of adult hippocampal neurogenesis and cognitive deficits. Autophagy 2020, 16, 512-530. [CrossRef] [PubMed]

135. Chen, G.; Kroemer, G.; Kepp, O. Mitophagy: An Emerging Role in Aging and Age-Associated Diseases. Front. Cell Dev. Biol. 2020, 8, 200. [CrossRef]

136. Kowalska, M.; Piekut, T.; Prendecki, M.; Sodel, A.; Kozubski, W.; Dorszewska, J. Mitochondrial and Nuclear DNA Oxidative Damage in Physiological and Pathological Aging. Dna Cell Biol. 2020, 39, 1410-1420. [CrossRef] [PubMed]

137. Ahlqvist, K.J.; Hamalainen, R.H.; Yatsuga, S.; Uutela, M.; Terzioglu, M.; Gotz, A.; Forsstrom, S.; Salven, P.; Angers-Loustau, A.; Kopra, O.H.; et al. Somatic progenitor cell vulnerability to mitochondrial DNA mutagenesis underlies progeroid phenotypes in Polg mutator mice. Cell Metab. 2012, 15, 100-109. [CrossRef]

138. Wang, W.; Esbensen, Y.; Kunke, D.; Suganthan, R.; Rachek, L.; Bjoras, M.; Eide, L. Mitochondrial DNA damage level determines neural stem cell differentiation fate. J. Neurosci. Off. J. Soc. Neurosci. 2011, 31, 9746-9751. [CrossRef] [PubMed]

139. Wang, W.; Osenbroch, P.; Skinnes, R.; Esbensen, Y.; Bjoras, M.; Eide, L. Mitochondrial DNA integrity is essential for mitochondrial maturation during differentiation of neural stem cells. Stem Cells 2010, 28, 2195-2204. [CrossRef]

140. Kang, E.; Wang, X.; Tippner-Hedges, R.; Ma, H.; Folmes, C.D.; Gutierrez, N.M.; Lee, Y.; Van Dyken, C.; Ahmed, R.; Li, Y.; et al. Age-Related Accumulation of Somatic Mitochondrial DNA Mutations in Adult-Derived Human iPSCs. Cell Stem Cell 2016, 18, 625-636. [CrossRef]

141. Masotti, A.; Celluzzi, A.; Petrini, S.; Bertini, E.; Zanni, G.; Compagnucci, C. Aged iPSCs display an uncommon mitochondrial appearance and fail to undergo in vitro neurogenesis. Aging 2014, 6, 1094-1108. [CrossRef] 
142. Vermulst, M.; Wanagat, J.; Kujoth, G.C.; Bielas, J.H.; Rabinovitch, P.S.; Prolla, T.A.; Loeb, L.A. DNA deletions and clonal mutations drive premature aging in mitochondrial mutator mice. Nat. Genet. 2008, 40, 392-394. [CrossRef]

143. Trifunovic, A.; Wredenberg, A.; Falkenberg, M.; Spelbrink, J.N.; Rovio, A.T.; Bruder, C.E.; Bohlooly, Y.M.; Gidlof, S.; Oldfors, A.; Wibom, R.; et al. Premature ageing in mice expressing defective mitochondrial DNA polymerase. Nature 2004, 429, 417-423. [CrossRef]

144. Stoll, E.A.; Cheung, W.; Mikheev, A.M.; Sweet, I.R.; Bielas, J.H.; Zhang, J.; Rostomily, R.C.; Horner, P.J. Aging neural progenitor cells have decreased mitochondrial content and lower oxidative metabolism. J. Biol. Chem. 2011, 286, 38592-38601. [CrossRef]

145. Manczak, M.; Anekonda, T.S.; Henson, E.; Park, B.S.; Quinn, J.; Reddy, P.H. Mitochondria are a direct site of A beta accumulation in Alzheimer's disease neurons: Implications for free radical generation and oxidative damage in disease progression. Hum. Mol. Genet. 2006, 15, 1437-1449. [CrossRef]

146. Onyango, I.G.; Dennis, J.; Khan, S.M. Mitochondrial Dysfunction in Alzheimer's Disease and the Rationale for Bioenergetics Based Therapies. Aging Dis. 2016, 7, 201-214. [CrossRef] [PubMed]

147. Marxreiter, F.; Regensburger, M.; Winkler, J. Adult neurogenesis in Parkinson's disease. Cell. Mol. Life Sci. CMLS 2013, 70, 459-473. [CrossRef]

148. Le Grand, J.N.; Gonzalez-Cano, L.; Pavlou, M.A.; Schwamborn, J.C. Neural stem cells in Parkinson's disease: A role for neurogenesis defects in onset and progression. Cell. Mol. Life Sci. CMLS 2015, 72, 773-797. [CrossRef] [PubMed]

149. Hollands, C.; Bartolotti, N.; Lazarov, O. Alzheimer's Disease and Hippocampal Adult Neurogenesis; Exploring Shared Mechanisms. Front. Neurosci. 2016, 10, 178. [CrossRef]

150. Cipriani, S.; Ferrer, I.; Aronica, E.; Kovacs, G.G.; Verney, C.; Nardelli, J.; Khung, S.; Delezoide, A.L.; Milenkovic, I.; Rasika, S.; et al. Hippocampal Radial Glial Subtypes and Their Neurogenic Potential in Human Fetuses and Healthy and Alzheimer's Disease Adults. Cereb. Cortex 2018, 28, 2458-2478. [CrossRef] [PubMed]

151. Moreno-Jimenez, E.P.; Flor-Garcia, M.; Terreros-Roncal, J.; Rabano, A.; Cafini, F.; Pallas-Bazarra, N.; Avila, J.; Llorens-Martin, M. Adult hippocampal neurogenesis is abundant in neurologically healthy subjects and drops sharply in patients with Alzheimer's disease. Nat. Med. 2019, 25, 554-560. [CrossRef] [PubMed]

152. Tobin, M.K.; Musaraca, K.; Disouky, A.; Shetti, A.; Bheri, A.; Honer, W.G.; Kim, N.; Dawe, R.J.; Bennett, D.A.; Arfanakis, K.; et al. Human Hippocampal Neurogenesis Persists in Aged Adults and Alzheimer's Disease Patients. Cell Stem Cell 2019, 24, 974-982.e3. [CrossRef]

153. Hoglinger, G.U.; Rizk, P.; Muriel, M.P.; Duyckaerts, C.; Oertel, W.H.; Caille, I.; Hirsch, E.C. Dopamine depletion impairs precursor cell proliferation in Parkinson disease. Nat. Neurosci. 2004, 7, 726-735. [CrossRef]

154. Van den Berge, S.A.; van Strien, M.E.; Korecka, J.A.; Dijkstra, A.A.; Sluijs, J.A.; Kooijman, L.; Eggers, R.; De Filippis, L.; Vescovi, A.L.; Verhaagen, J.; et al. The proliferative capacity of the subventricular zone is maintained in the parkinsonian brain. Brain J. Neurol. 2011, 134 Pt 11, 3249-3263. [CrossRef]

155. Crews, L.; Adame, A.; Patrick, C.; Delaney, A.; Pham, E.; Rockenstein, E.; Hansen, L.; Masliah, E. Increased BMP6 levels in the brains of Alzheimer's disease patients and APP transgenic mice are accompanied by impaired neurogenesis. J. Neurosci. Off. J. Soc. Neurosci. 2010, 30, 12252-12262. [CrossRef] [PubMed]

156. Winner, B.; Melrose, H.L.; Zhao, C.; Hinkle, K.M.; Yue, M.; Kent, C.; Braithwaite, A.T.; Ogholikhan, S.; Aigner, R.; Winkler, J.; et al. Adult neurogenesis and neurite outgrowth are impaired in LRRK2 G2019S mice. Neurobiol. Dis. 2011, 41, 706-716. [CrossRef] [PubMed]

157. Winner, B.; Rockenstein, E.; Lie, D.C.; Aigner, R.; Mante, M.; Bogdahn, U.; Couillard-Despres, S.; Masliah, E.; Winkler, J. Mutant alpha-synuclein exacerbates age-related decrease of neurogenesis. Neurobiol. Aging 2008, 29, 913-925. [CrossRef] [PubMed]

158. Zhang, X.M.; Anwar, S.; Kim, Y.; Brown, J.; Comte, I.; Cai, H.; Cai, N.N.; Wade-Martins, R.; Szele, F.G. The A30P alpha-synuclein mutation decreases subventricular zone proliferation. Hum. Mol. Genet. 2019, 28, 2283-2294. [CrossRef]

159. Walter, J.; Bolognin, S.; Antony, P.M.A.; Nickels, S.L.; Poovathingal, S.K.; Salamanca, L.; Magni, S.; Perfeito, R.; Hoel, F.; Qing, X.; et al. Neural Stem Cells of Parkinson's Disease Patients Exhibit Aberrant Mitochondrial Morphology and Functionality. Stem Cell Rep. 2019, 12, 878-889. [CrossRef]

160. Liu, G.H.; Qu, J.; Suzuki, K.; Nivet, E.; Li, M.; Montserrat, N.; Yi, F.; Xu, X.; Ruiz, S.; Zhang, W.; et al. Progressive degeneration of human neural stem cells caused by pathogenic LRRK2. Nature 2012, 491, 603-607. [CrossRef]

161. Kim, D.; Cho, J.; Kang, H. Protective effect of exercise training against the progression of Alzheimer's disease in 3xTg-AD mice. Behav. Brain Res. 2019, 374, 112105. [CrossRef] [PubMed]

162. Martin-Maestro, P.; Sproul, A.; Martinez, H.; Paquet, D.; Gerges, M.; Noggle, S.; Starkov, A.A. Autophagy Induction by Bexarotene Promotes Mitophagy in Presenilin 1 Familial Alzheimer's Disease iPSC-Derived Neural Stem Cells. Mol. Neurobiol. 2019, 56, 8220-8236. [CrossRef] [PubMed]

163. Ghosal, K.; Fan, Q.; Dawson, H.N.; Pimplikar, S.W. Tau Protein Mediates APP Intracellular Domain (AICD)-Induced Alzheimer'sLike Pathological Features in Mice. PLOS ONE 2016, 11, e0159435. [CrossRef] [PubMed]

164. Veeraraghavalu, K.; Choi, S.H.; Zhang, X.; Sisodia, S.S. Endogenous expression of FAD-linked PS1 impairs proliferation, neuronal differentiation and survival of adult hippocampal progenitors. Mol. Neurodegener. 2013, 8, 41. [CrossRef]

165. Amber, S.; Sumera; Mirza, F.; Asif, J.; Hassan, D.; Ahmed, T.; Zahid, S. Amyloid-beta Induced Neurotoxicity Impairs Cognition and Adult Hippocampal Neurogenesis in a Mouse Model for Alzheimer's Disease. Curr. Alzheimer Res. 2020, 17, 1033-1042. [CrossRef] 
166. Demars, M.; Hu, Y.S.; Gadadhar, A.; Lazarov, O. Impaired neurogenesis is an early event in the etiology of familial Alzheimer's disease in transgenic mice. J. Neurosci. Res. 2010, 88, 2103-2117. [CrossRef]

167. Reeve, A.K.; Ludtmann, M.H.; Angelova, P.R.; Simcox, E.M.; Horrocks, M.H.; Klenerman, D.; Gandhi, S.; Turnbull, D.M.; Abramov, A.Y. Aggregated alpha-synuclein and complex I deficiency: Exploration of their relationship in differentiated neurons. Cell Death Dis. 2015, 6, e1820. [CrossRef] [PubMed]

168. Shlevkov, E.; Kramer, T.; Schapansky, J.; LaVoie, M.J.; Schwarz, T.L. Miro phosphorylation sites regulate Parkin recruitment and mitochondrial motility. Proc. Natl. Acad. Sci. USA 2016, 113, E6097-E6106. [CrossRef] [PubMed]

169. Saotome, M.; Safiulina, D.; Szabadkai, G.; Das, S.; Fransson, A.; Aspenstrom, P.; Rizzuto, R.; Hajnoczky, G. Bidirectional Ca ${ }^{2+}$ dependent control of mitochondrial dynamics by the Miro GTPase. Proc. Natl. Acad. Sci. USA 2008, 105, 20728-20733. [CrossRef]

170. Markowicz-Piasecka, M.; Sikora, J.; Szydlowska, A.; Skupien, A.; Mikiciuk-Olasik, E.; Huttunen, K.M. Metformin-A Future Therapy for Neurodegenerative Diseases: Theme: Drug Discovery, Development and Delivery in Alzheimer's Disease Guest Editor: Davide Brambilla. Pharm. Res. 2017, 34, 2614-2627. [CrossRef]

171. Fatt, M.; Hsu, K.; He, L.; Wondisford, F.; Miller, F.D.; Kaplan, D.R.; Wang, J. Metformin Acts on Two Different Molecular Pathways to Enhance Adult Neural Precursor Proliferation/Self-Renewal and Differentiation. Stem Cell Rep. 2015, 5, 988-995. [CrossRef]

172. Kang, H.; Khang, R.; Ham, S.; Jeong, G.R.; Kim, H.; Jo, M.; Lee, B.D.; Lee, Y.I.; Jo, A.; Park, C.; et al. Activation of the ATF2/CREB-PGC-1alpha pathway by metformin leads to dopaminergic neuroprotection. Oncotarget 2017, 8, 48603-48618. [CrossRef] [PubMed]

173. Tanokashira, D.; Kurata, E.; Fukuokaya, W.; Kawabe, K.; Kashiwada, M.; Takeuchi, H.; Nakazato, M.; Taguchi, A. Metformin treatment ameliorates diabetes-associated decline in hippocampal neurogenesis and memory via phosphorylation of insulin receptor substrate 1. FEBS Open Bio 2018, 8, 1104-1118. [CrossRef] [PubMed]

174. Wang, J.; Gallagher, D.; DeVito, L.M.; Cancino, G.I.; Tsui, D.; He, L.; Keller, G.M.; Frankland, P.W.; Kaplan, D.R.; Miller, F.D. Metformin activates an atypical PKC-CBP pathway to promote neurogenesis and enhance spatial memory formation. Cell Stem Cell 2012, 11, 23-35. [CrossRef]

175. Yuan, R.; Wang, Y.; Li, Q.; Zhen, F.; Li, X.; Lai, Q.; Hu, P.; Wang, X.; Zhu, Y.; Fan, H.; et al. Metformin reduces neuronal damage and promotes neuroblast proliferation and differentiation in a cerebral ischemia/reperfusion rat model. Neuroreport 2019, 30, 232-240. [CrossRef] [PubMed]

176. Suwa, M.; Egashira, T.; Nakano, H.; Sasaki, H.; Kumagai, S. Metformin increases the PGC-1alpha protein and oxidative enzyme activities possibly via AMPK phosphorylation in skeletal muscle in vivo. J. Appl. Physiol. 2006, 101, 1685-1692. [CrossRef]

177. Kane, D.A.; Anderson, E.J.; Price, J.W., III; Woodlief, T.L.; Lin, C.T.; Bikman, B.T.; Cortright, R.N.; Neufer, P.D. Metformin selectively attenuates mitochondrial $\mathrm{H} 2 \mathrm{O} 2$ emission without affecting respiratory capacity in skeletal muscle of obese rats. Free Radic. Biol. Med. 2010, 49, 1082-1087. [CrossRef]

178. Ruddy, R.M.; Adams, K.V.; Morshead, C.M. Age- and sex-dependent effects of metformin on neural precursor cells and cognitive recovery in a model of neonatal stroke. Sci. Adv. 2019, 5, eaax1912. [CrossRef] [PubMed]

179. DiTacchio, K.A.; Heinemann, S.F.; Dziewczapolski, G. Metformin treatment alters memory function in a mouse model of Alzheimer's disease. J. Alzheimer's Dis. 2015, 44, 43-48. [CrossRef] [PubMed]

180. Barini, E.; Antico, O.; Zhao, Y.; Asta, F.; Tucci, V.; Catelani, T.; Marotta, R.; Xu, H.; Gasparini, L. Metformin promotes tau aggregation and exacerbates abnormal behavior in a mouse model of tauopathy. Mol. Neurodegener. 2016, 11, 16. [CrossRef] [PubMed]

181. Stockburger, C.; Miano, D.; Pallas, T.; Friedland, K.; Muller, W.E. Enhanced Neuroplasticity by the Metabolic Enhancer Piracetam Associated with Improved Mitochondrial Dynamics and Altered Permeability Transition Pore Function. Neural Plast. 2016, 2016, 8075903. [CrossRef] [PubMed]

182. Verdin, E. NAD(+) in aging, metabolism, and neurodegeneration. Science 2015, 350, 1208-1213. [CrossRef]

183. Imai, S.; Guarente, L. NAD+ and sirtuins in aging and disease. Trends Cell Biol. 2014, 24, 464-471. [CrossRef] [PubMed]

184. Watroba, M.; Szukiewicz, D. The role of sirtuins in aging and age-related diseases. Adv. Med Sci. 2016, 61, 52-62. [CrossRef] [PubMed]

185. Ding, Y.; Yang, H.; Wang, Y.; Chen, J.; Ji, Z.; Sun, H. Sirtuin 3 is required for osteogenic differentiation through maintenance of PGC-1a-SOD2-mediated regulation of mitochondrial function. Int. J. Biol. Sci. 2017, 13, 254-264. [CrossRef]

186. Stein, L.R.; Imai, S. Specific ablation of Nampt in adult neural stem cells recapitulates their functional defects during aging. Embo J. 2014, 33, 1321-1340. [CrossRef]

187. Lehmann, S.; Costa, A.C.; Celardo, I.; Loh, S.H.; Martins, L.M. Parp mutations protect against mitochondrial dysfunction and neurodegeneration in a PARKIN model of Parkinson's disease. Cell Death Dis. 2016, 7, e2166. [CrossRef] [PubMed]

188. Liu, D.; Pitta, M.; Jiang, H.; Lee, J.H.; Zhang, G.; Chen, X.; Kawamoto, E.M.; Mattson, M.P. Nicotinamide forestalls pathology and cognitive decline in Alzheimer mice: Evidence for improved neuronal bioenergetics and autophagy procession. Neurobiol. Aging 2013, 34, 1564-1580. [CrossRef]

189. Long, A.N.; Owens, K.; Schlappal, A.E.; Kristian, T.; Fishman, P.S.; Schuh, R.A. Effect of nicotinamide mononucleotide on brain mitochondrial respiratory deficits in an Alzheimer's disease-relevant murine model. BMC Neurol. 2015, 15, 19. [CrossRef]

190. Hou, Y.; Lautrup, S.; Cordonnier, S.; Wang, Y.; Croteau, D.L.; Zavala, E.; Zhang, Y.; Moritoh, K.; O'Connell, J.F.; Baptiste, B.A.; et al. $\mathrm{NAD}(+)$ supplementation normalizes key Alzheimer's features and DNA damage responses in a new AD mouse model with introduced DNA repair deficiency. Proc. Natl. Acad. Sci. USA 2018, 115, E1876-E1885. [CrossRef] 
191. Stein, L.R.; Wozniak, D.F.; Dearborn, J.T.; Kubota, S.; Apte, R.S.; Izumi, Y.; Zorumski, C.F.; Imai, S. Expression of Nampt in hippocampal and cortical excitatory neurons is critical for cognitive function. J. Neurosci. Off. J. Soc. Neurosci. 2014, 34, 5800-5815. [CrossRef]

192. Gusdon, A.M.; Callio, J.; Distefano, G.; O’Doherty, R.M.; Goodpaster, B.H.; Coen, P.M.; Chu, C.T. Exercise increases mitochondrial complex I activity and DRP1 expression in the brains of aged mice. Exp. Gerontol. 2017, 90, 1-13. [CrossRef] [PubMed]

193. Marques-Aleixo, I.; Santos-Alves, E.; Oliveira, P.J.; Moreira, P.I.; Magalhaes, J.; Ascensao, A. The beneficial role of exercise in mitigating doxorubicin-induced Mitochondrionopathy. Biochim. Biophys. Acta. Rev. Cancer 2018, 1869, 189-199. [CrossRef] [PubMed]

194. Marques-Aleixo, I.; Santos-Alves, E.; Balca, M.M.; Rizo-Roca, D.; Moreira, P.I.; Oliveira, P.J.; Magalhaes, J.; Ascensao, A. Physical exercise improves brain cortex and cerebellum mitochondrial bioenergetics and alters apoptotic, dynamic and auto(mito)phagy markers. Neuroscience 2015, 301, 480-495. [CrossRef]

195. Herbst, E.A.; Holloway, G.P. Exercise training normalizes mitochondrial respiratory capacity within the striatum of the R6/1 model of Huntington's disease. Neuroscience 2015, 303, 515-523. [CrossRef]

196. Chao, F.; Jiang, L.; Zhang, Y.; Zhou, C.; Zhang, L.; Tang, J.; Liang, X.; Qi, Y.; Zhu, Y.; Ma, J.; et al. Stereological Investigation of the Effects of Treadmill Running Exercise on the Hippocampal Neurons in Middle-Aged APP/PS1 Transgenic Mice. J. Alzheimer's Dis. 2018, 63, 689-703. [CrossRef]

197. Pinar, C.; Yau, S.Y.; Sharp, Z.; Shamei, A.; Fontaine, C.J.; Meconi, A.L.; Lottenberg, C.P.; Christie, B.R. Effects of Voluntary Exercise on Cell Proliferation and Neurogenesis in the Dentate Gyrus of Adult FMR1 Knockout Mice. Brain Plast. 2018, 4, 185-195. [CrossRef] [PubMed]

198. Kempermann, G. Environmental enrichment, new neurons and the neurobiology of individuality. Nat. Rev. Neurosci. 2019, 20, 235-245. [CrossRef]

199. Van Praag, H.; Kempermann, G.; Gage, F.H. Running increases cell proliferation and neurogenesis in the adult mouse dentate gyrus. Nat. Neurosci. 1999, 2, 266-270. [CrossRef]

200. Van Praag, H.; Christie, B.R.; Sejnowski, T.J.; Gage, F.H. Running enhances neurogenesis, learning, and long-term potentiation in mice. Proc. Natl. Acad. Sci. USA 1999, 96, 13427-13431. [CrossRef]

201. Godoy, J.A.; Arrazola, M.S.; Ordenes, D.; Silva-Alvarez, C.; Braidy, N.; Inestrosa, N.C. Wnt-5a ligand modulates mitochondrial fission-fusion in rat hippocampal neurons. J. Biol. Chem. 2014, 289, 36179-36193. [CrossRef] [PubMed]

202. Richetin, K.; Moulis, M.; Millet, A.; Arrazola, M.S.; Andraini, T.; Hua, J.; Davezac, N.; Roybon, L.; Belenguer, P.; Miquel, M.C.; et al. Amplifying mitochondrial function rescues adult neurogenesis in a mouse model of Alzheimer's disease. Neurobiol. Dis. 2017, 102, 113-124. [CrossRef] [PubMed]

203. Bartolome, F.; de la Cueva, M.; Pascual, C.; Antequera, D.; Fernandez, T.; Gil, C.; Martinez, A.; Carro, E. Amyloid beta-induced impairments on mitochondrial dynamics, hippocampal neurogenesis, and memory are restored by phosphodiesterase 7 inhibition. Alzheimer's Res. Ther. 2018, 10, 24. [CrossRef] [PubMed]

204. Lenhausen, A.M.; Wilkinson, A.S.; Lewis, E.M.; Dailey, K.M.; Scott, A.J.; Khan, S.; Wilkinson, J.C. Apoptosis Inducing Factor Binding Protein PGAM5 Triggers Mitophagic Cell Death That Is Inhibited by the Ubiquitin Ligase Activity of X-Linked Inhibitor of Apoptosis. Biochemistry 2016, 55, 3285-3302. [CrossRef]

205. Kim, E.H.; Choi, K.S. A critical role of superoxide anion in selenite-induced mitophagic cell death. Autophagy 2008, 4, 76-78. [CrossRef] [PubMed]

206. Baldelli, S.; Aquilano, K.; Ciriolo, M.R. PGC-1alpha buffers ROS-mediated removal of mitochondria during myogenesis. Cell Death Dis. 2014, 5, e1515. [CrossRef]

207. Osborn, T.M.; Hallett, P.J.; Schumacher, J.M.; Isacson, O. Advantages and Recent Developments of Autologous Cell Therapy for Parkinson's Disease Patients. Front. Cell. Neurosci. 2020, 14, 58. [CrossRef]

208. Pajer, K.; Nemes, C.; Berzsenyi, S.; Kovacs, K.A.; Pirity, M.K.; Pajenda, G.; Nogradi, A.; Dinnyes, A. Grafted murine induced pluripotent stem cells prevent death of injured rat motoneurons otherwise destined to die. Exp. Neurol. 2015, 269, 188-201. [CrossRef] [PubMed]

209. Hallett, P.J.; Deleidi, M.; Astradsson, A.; Smith, G.A.; Cooper, O.; Osborn, T.M.; Sundberg, M.; Moore, M.A.; Perez-Torres, E.; Brownell, A.L.; et al. Successful function of autologous iPSC-derived dopamine neurons following transplantation in a non-human primate model of Parkinson's disease. Cell Stem Cell 2015, 16, 269-274. [CrossRef]

210. Lu, P.; Woodruff, G.; Wang, Y.; Graham, L.; Hunt, M.; Wu, D.; Boehle, E.; Ahmad, R.; Poplawski, G.; Brock, J.; et al. Long-distance axonal growth from human induced pluripotent stem cells after spinal cord injury. Neuron 2014, 83, 789-796. [CrossRef]

211. Yin, X.; Xu, J.C.; Cho, G.S.; Kwon, C.; Dawson, T.M.; Dawson, V.L. Neurons Derived from Human Induced Pluripotent Stem Cells Integrate into Rat Brain Circuits and Maintain Both Excitatory and Inhibitory Synaptic Activities. eNeuro 2019, 6. [CrossRef] [PubMed]

212. Strnadel, J.; Carromeu, C.; Bardy, C.; Navarro, M.; Platoshyn, O.; Glud, A.N.; Marsala, S.; Kafka, J.; Miyanohara, A.; Kato, T., Jr.; et al. Survival of syngeneic and allogeneic iPSC-derived neural precursors after spinal grafting in minipigs. Sci. Transl. Med. 2018, 10, eaam6651. [CrossRef] [PubMed] 